bioRxiv preprint doi: https://doi.org/10.1101/2021.01.24.427995; this version posted June 3, 2021. The copyright holder for this preprint (which was not certified by peer review) is the author/funder, who has granted bioRxiv a license to display the preprint in perpetuity. It is made available under aCC-BY-NC-ND 4.0 International license.

\title{
Novel bisubstrate inhibitors for protein N-terminal acetyltransferase D
}

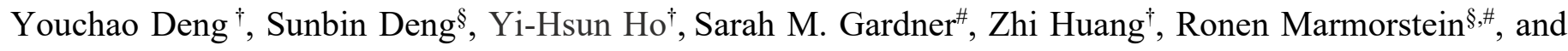
Rong Huang ${ }^{*}, \dagger$

†Department of Medicinal Chemistry and Molecular Pharmacology, Purdue Institute for Drug Discovery, Purdue University Center for Cancer Research, Purdue University, West Lafayette, Indiana 47907, United States

${ }^{\S}$ Department of Chemistry, University of Pennsylvania, Philadelphia, Pennsylvania 19104, United States

\#Department of Biochemistry and Biophysics, Abramson Family Cancer Research Institute, Graduate Group in Biochemistry and Molecular Biophysics, Perelman School of Medicine, University of Pennsylvania, Philadelphia, Pennsylvania 19104, United States

*Corresponding Author: huang-r@purdue.edu 
ABSTRACT: Protein N-terminal acetyltransferase D (NatD, NAA40) that specifically acetylates the alpha-Nterminus of histone $\mathrm{H} 4$ and $\mathrm{H} 2 \mathrm{~A}$ has been implicated in various diseases, but no inhibitor has been reported for this important enzyme. Based on the acetyl transfer mechanism of NatD, we designed and prepared a series of highly potent NatD bisubstrate inhibitors by covalently linking coenzyme A to different peptide substrates via an acetyl or propionyl spacer. The most potent bisubstrate inhibitor displayed an apparent $K_{\mathrm{i}}$ value of 1.0 nM. Biochemical studies indicated that bisubstrate inhibitor is competitive to the peptide substrate and noncompetitive to the cofactor, suggesting NatD undergoes an ordered Bi-Bi mechanism. We also demonstrated that these inhibitors are highly specific towards NatD, displaying about 1,000-fold selectivity over other closely related acetyltransferases. High-resolution crystal structures of NatD bound to two of these inhibitors revealed the molecular basis for their selectivity and inhibition mechanism, providing a rational path for future inhibitor development. 


\section{INTRODUCTION}

$\alpha-\mathrm{N}$-terminal acetylation ( $\mathrm{N \alpha}$-acetylation) is a ubiquitous protein modification that occurs on $80-90 \%$ of human proteins ${ }^{1}$. It is essential for various biological functions, including protein-protein interactions, protein complex formation, cellular apoptosis, rDNA transcriptional regulation, protein subcellular localization, and degradation ${ }^{2-4}$. This modification is catalyzed by protein $\mathrm{N}$-terminal acetyltransferases (NATs) that transfer an acetyl group from the donor acetyl coenzyme $\mathrm{A}(\mathrm{AcCoA})$ onto the $\mathrm{N} \alpha$-amino group of protein substrates. To date, eight members of eukaryotic NATs (NatA-NatH) have been reported ${ }^{5}$. Among them, NatA and NatD acetylate the nascent chain after the initiator methionine is cleaved ${ }^{6}$. NatA is a multisubunit enzyme, acetylating $\sim 40 \%$ of human proteins that contain small and uncharged first residues ${ }^{1,6}$. In contrast, NatD (NAA40) is a monomeric protein showing extremely high substrate specificity for histone proteins $\mathrm{H} 2 \mathrm{~A}$ and H4 that have the same N-terminal sequence SGRGK ${ }^{7,8}$.

$\mathrm{N} \alpha$-acetylation on $\mathrm{H} 4$ has diverse biological functions and implications in tumorigenesis ${ }^{2,9,7}$. Depletion of NatD induces apoptosis through the mitochondrial pathway in colorectal cancer cells ${ }^{10}$. In addition, NatD is downregulated in hepatocellular carcinoma tissues and upregulated in primary human lung cancer tissues ${ }^{11}$. As the function of histone $\mathrm{H} 4 \mathrm{~N} \alpha$-acetylation has recently come to light, it has been shown to regulate crosstalk with arginine methylation, lysine acetylation, and serine phosphorylation on $\mathrm{H} 4{ }^{12,13}$. For example, $\mathrm{N} \alpha$-acetylation of $\mathrm{H} 4$ stimulates ribosomal DNA expression by inhibiting asymmetric dimethylation of Arg3 on H4 (H4R3me2a), consistent with its critical role in cell growth ${ }^{12,13}$. Na-acetylation of $\mathrm{H} 4$ suppresses Ser1 phosphorylation and induces the expression of Slug transcription to promote the epithelialto-mesenchymal transition in lung cancer, suggesting that the acetyltransferase activity of NatD is critical for Slug regulation ${ }^{13}$. In addition, $\mathrm{N} \alpha$-acetylation of $\mathrm{H} 4$ promotes the expression of oncogenes through upregulation of protein arginine methyltransferase 5 in colorectal cancer cells ${ }^{10}$. Based on these disease connections, NatD has surfaced as a new therapeutic target. Hence, potent and selective NatD inhibitors would be valuable probes to interrogate its functions and therapeutical potential. However, there is no NatD inhibitor reported to date.

The co-crystal structure of the ternary NatD $\backslash$ CoAISGRGK complex (PDB: 4U9W) revealed that its substrate peptide (SGRGK) is inserted into a highly acidic binding pocket of NatD, and biochemical studies 
supported the importance of the first 4 residues (SGRG) of the cognate substrate for specific recognition ${ }^{8}$. Although the kinetic mechanism of NatD has not yet been elucidated, both NatA and NatE have been shown to follow an ordered Bi-Bi mechanism ${ }^{14-16}$. Structural alignment of NatD with NatA infers a similar mechanism as NatA ${ }^{8}$. Furthermore, upon mutation of an active-site $\mathrm{C} 137$, a previously suggested catalytic residue that forms an acetyl-NatD intermediate, hNatD remained largely active, supporting a direct transfer of the acetyl group through a $\mathrm{Bi}-\mathrm{Bi}$ mechanism ${ }^{8}$. Based on these observations, we hypothesized that bisubstrate analogues could provide potent inhibitors for NatD. Bisubstrate analogues have previously been used to help elucidate the catalytic mechanism of other NATs and to develop valuable tool compounds, usually displaying $\mathrm{IC}_{50}$ values within a low micromolar to high nanomolar range against $S p \mathrm{NatA}^{14}, \mathrm{hNatB}^{17}, \mathrm{hNatF}{ }^{18}, \mathrm{NatH}^{19}$. In the study presented here, we developed highly potent and selective NatD bisubstrate inhibitors. Moreover, the X-ray crystal structures of NatD bound to two bisubstrate inhibitors have been determined to elucidate the molecular interactions, thus paving the way for the structure-based development of more drug-like NatD inhibitors.

\section{RESULTS AND DISCUSSION}

Inhibitor Design. Bisubstrate analogues that covalently connect cofactor and short peptide substrate with a linker have been reported for targeting a variety of transferases, such as methyltransferases and acetyltransferases ${ }^{20,21}$. Based on the co-crystal structure of the NatD/CoA/SGRGK ternary complex (PDB: 4U9W), the linear distance between the $\alpha$-nitrogen atom of the first Ser residue and the sulfur atom of CoA was measured to be about $3.1 \AA$ (Figure 1$)^{8}$. Therefore, we proposed to connect the N $\alpha$-amines of different peptide substrates and the thiol group of CoA through either an acetyl or propionyl linker to prepare bisubstrate analogues to mimic the transition state, which would be predicted to provide potent and selective inhibitors for NatD. 
bioRxiv preprint doi: https://doi.org/10.1101/2021.01.24.427995; this version posted June 3, 2021. The copyright holder for this preprint (which was not certified by peer review) is the author/funder, who has granted bioRxiv a license to display the preprint in perpetuity. It is made available under aCC-BY-NC-ND 4.0 International license.

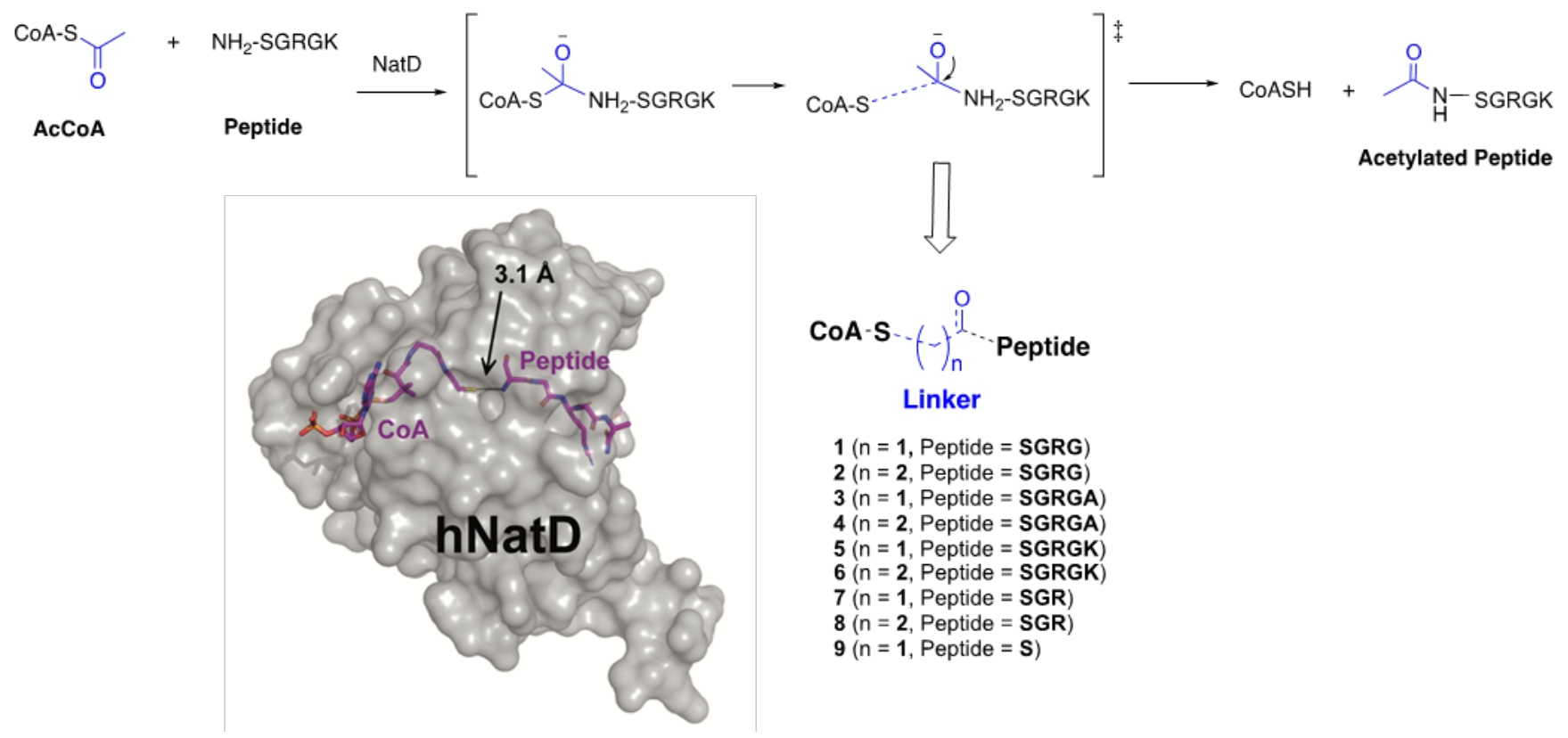

Figure 1. Inhibitor design strategy. The distance between the sulfur atom of CoA (magenta stick) and the $\mathrm{N} \alpha$ nitrogen atom of peptide (magenta stick) is $3.1 \AA$ in the ternary complex of the NatD/CoA/SGRGK (PDB: 4U9W), where NatD is in surface view (grey). The designed NatD bisubstrate analogues $\mathbf{1}-\mathbf{9}$ are illustrated.

Inhibitor Synthesis. Peptides were prepared on Rink amide resin following a standard Fmoc solid-phase peptide synthesis protocol. 2-bromoacetic acid or 3-bromopropionic acid was coupled with the free N-terminal amine of the peptide on the resin. Subsequent cleavage with the cocktail consisting of trifluoroacetic acid (TFA)/water $\left(\mathrm{H}_{2} \mathrm{O}\right) /$ triisopropylsilane $(95: 2.5: 2.5)$ and purification through high-performance liquid chromatography (HPLC) provided the purified bromopeptides, which were then reacted with coenzyme A trilithium salt dihydrate in the triethylammonium bicarbonate buffer ${ }^{20}$. The resulting mixture was purified by HPLC to afford the desired bisubstrate analogues 1-9. 


\section{Scheme 1. Synthetic route for the bisubstrate analogues.}

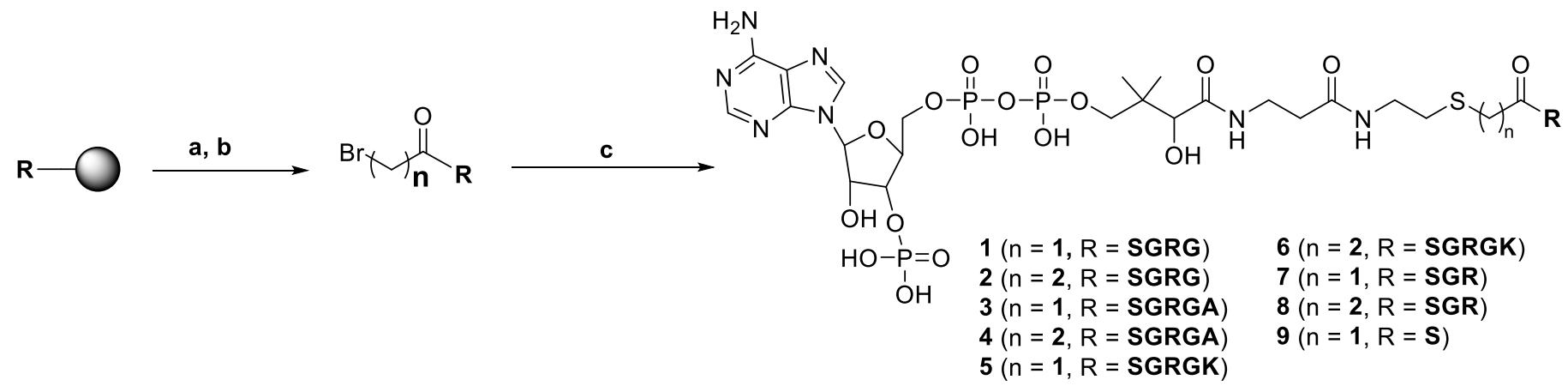

Reagents and conditions: (a) 2-Bromoacetic acid or 3-Bromopropionic acid, DIC, HOBt, DMF, r.t., overnight;

(b) TFA/ TIPS/water(95/2.5/2.5), r.t., 4 h, 34-56\% in two steps; (c) CoASH, triethylammonium bicarbonate buffer, pH $8.4 \pm 0.1$, r.t., 48 h, 33-55\%.

Structure-Activity Relationship Studies. All synthesized bisubstrate analogues were first evaluated with an established fluorescence assay ${ }^{22}$. Initial testing was performed in the presence of both AcCoA and an H4-8 peptide (SGRGKGGK-CONH$\left.{ }_{2}\right)$ at their respective Michaelis constant $\left(K_{\mathrm{m}}\right)$ values. But resulting $\mathrm{IC}_{50}$ values of compounds 1-8 were close to or lower than the concentration of NatD (45 nM) in the assay (Table 1, Figure $3 \mathrm{Sa}-\mathrm{b})$ ), suggesting that they are slow and tight-binding inhibitors ${ }^{23,}{ }^{24}$. To understand the contribution of each component of the bisubstrate analogue to the NatD inhibition, we designed and prepared two control compounds 9 and 10, where 9 connecting CoA with only Ser residue and $\mathbf{1 0}$ without the CoA moiety. Compound 9 displayed an $\mathrm{IC}_{50}$ value of $218 \mathrm{nM}$, which was over 4-fold reduction compared to those analogues containing 3-5 mer peptides. This result corroborated that the first three amino acids contribute significantly to the interaction with NatD as suggested by the ternary complex of NatD/CoA/SGRGK ${ }^{8}$. Whereas, inhibitory activity of $\mathbf{1 0}$ lost over 1,000-fold even compared to $\mathbf{9}$, supporting the importance of each moiety for potent inhibition of NatD. As fluorescence assay exhibited a narrow dynamic range (less than 2fold) to fully characterize those slow and tight-binding inhibitors 1-8, we applied an orthogonal radioactive assay to directly monitor the production of acetylated peptide under a similar condition with both AcCoA and H4-19 peptide substrate (SGRGKGGKGLGKGGAKRHR-COOH; GenScript) at their $4 \mathrm{x} K_{\mathrm{m}}$ values as radioactive assay is generally more sensitive ${ }^{8}$. The difference among $\mathbf{1 - 8}$ was more salient in the radioactive 
assay compared to the fluorescence assay, as tenfold difference was observed among $\mathrm{IC}_{50}$ values of 1-8 ranging from $4 \mathrm{nM}$ to $41 \mathrm{nM}$ for NatD (Table 1, Figure 3Sc,d). Inhibitory activity was reduced when only Ser was incorporated in the substrate moiety, displaying an $\mathrm{IC}_{50}$ value over $370 \mathrm{nM}$ and supporting the importance of the first three amino acids. Meanwhile, removal of the CoA moiety also abolished the inhibitory activity, as propionyl-SGRGK 10 exhibited an $\mathrm{IC}_{50}$ of over $500 \mu \mathrm{M}$. Even under this saturated condition, 18 showed tight-binding inhibition as their $\mathrm{IC}_{50}$ values were below the concentration of NatD, Morrison's quadratic equation was applied to analyze the concentration-response data to define their apparent $K_{\mathrm{i}}$ values ${ }^{24}$. The most potent inhibitor $\mathbf{6}$ that links CoA and SGRGK peptide through a propionyl linker demonstrated a $K_{\text {i,app }}$ value of $1.0 \mathrm{nM}$ (Table 1, Figure 2a,b), which is 2-fold and 8.4-fold higher than $\mathbf{2}$ and $\mathbf{8}$, respectively. For bisubstrate analogues containing either a tetrapeptide SGRG or pentapeptide SGRGK, a propionyl linker was more favorable than an acetyl linker as inhibitory activity was 2- to 4-fold better. However, acetyl linker was better than a propionyl linker for the bisubstrate ananlogs that only contained a tripeptide SGR, as 7 was 2-fold more potent than $\mathbf{8}$. For the bisubstrate analogs containing a pentapeptide SGRGA, both linkers were acceptable and showed more similar potency. When three to five amino acids were incorporated in the bisubstrate analogue, both acetyl and propionyl linkers within the bisubstrate analogues can be accommodated by NatD.

Table 1. Inhibition activities of the bisubstrate inhibitors

\begin{tabular}{lllll}
\hline $\mathrm{ID}$ & Structure & $\mathrm{IC}_{50}(\mathrm{nM})^{\mathrm{a}}$ & $\mathrm{IC}_{50}(\mathrm{nM})^{\mathrm{b}}$ & ${\text { Morrison } K_{\mathrm{i}, \text { app }}(\mathrm{nM})^{\mathrm{c}}}^{\mathrm{c}}$ \\
\hline $\mathbf{1}$ & CoA-C2-SGRG & $48 \pm 2.5$ & $27 \pm 3.8$ & $4.4 \pm 0.85$ \\
$\mathbf{2}$ & CoA-C3-SGRG & $48 \pm 8.4$ & $7.1 \pm 1.8$ & $2.1 \pm 0.32$ \\
$\mathbf{3}$ & CoA-C2-SGRGA & $41 \pm 3.8$ & $25 \pm 3.4$ & $6.2 \pm 1.5$ \\
$\mathbf{4}$ & CoA-C3-SGRGA & $32 \pm 2.5$ & $35 \pm 5.4$ & $8.7 \pm 1.8$ \\
$\mathbf{5}$ & CoA-C2-SGRGK & $35 \pm 6.0$ & $20 \pm 3.2$ & $4.4 \pm 0.58$ \\
$\mathbf{6}$ & CoA-C3-SGRGK & $40 \pm 7.7$ & $4.1 \pm 0.40$ & $1.0 \pm 0.11$ \\
$\mathbf{7}$ & CoA-C2-SGR & $29 \pm 5.6$ & $16 \pm 4.9$ & $3.7 \pm 0.71$ \\
$\mathbf{8}$ & CoA-C3-SGR & $40 \pm 3.9$ & $41 \pm 6.7$ & $8.4 \pm 1.6$ \\
$\mathbf{9}$ & CoA-C2-S & $218 \pm 28$ & $>370$ & NA \\
$\mathbf{1 0}$ & Propionyl-SGRGK & $330 \pm 35 \mu \mathrm{M}$ & $>500 \mu \mathrm{M}$ & NA \\
\hline
\end{tabular}

Note: a) Inhibition activities were measured in duplicate $(n=2)$ in the fluorescence assay with both AcCoA and peptide substrate were at their respective $K_{\mathrm{m}}$ values. b) $\mathrm{IC}_{50}$ values were determined in triplicate $(\mathrm{n}=3)$ in the radioactive assay 
with both AcCoA and peptide substrate were at their respective $4 \mathrm{x} K_{\mathrm{m}}$ values. C) Apparent $K_{\mathrm{i}}$ values were analyzed by fitting concentration-response data obtained in the radioactive assay to Morrison's quadratic equation for 1-8. $\mathrm{IC}_{50}$ and $K_{\text {i,app }}$ values were presented as mean \pm standard deviation (SD). NA: not applied.
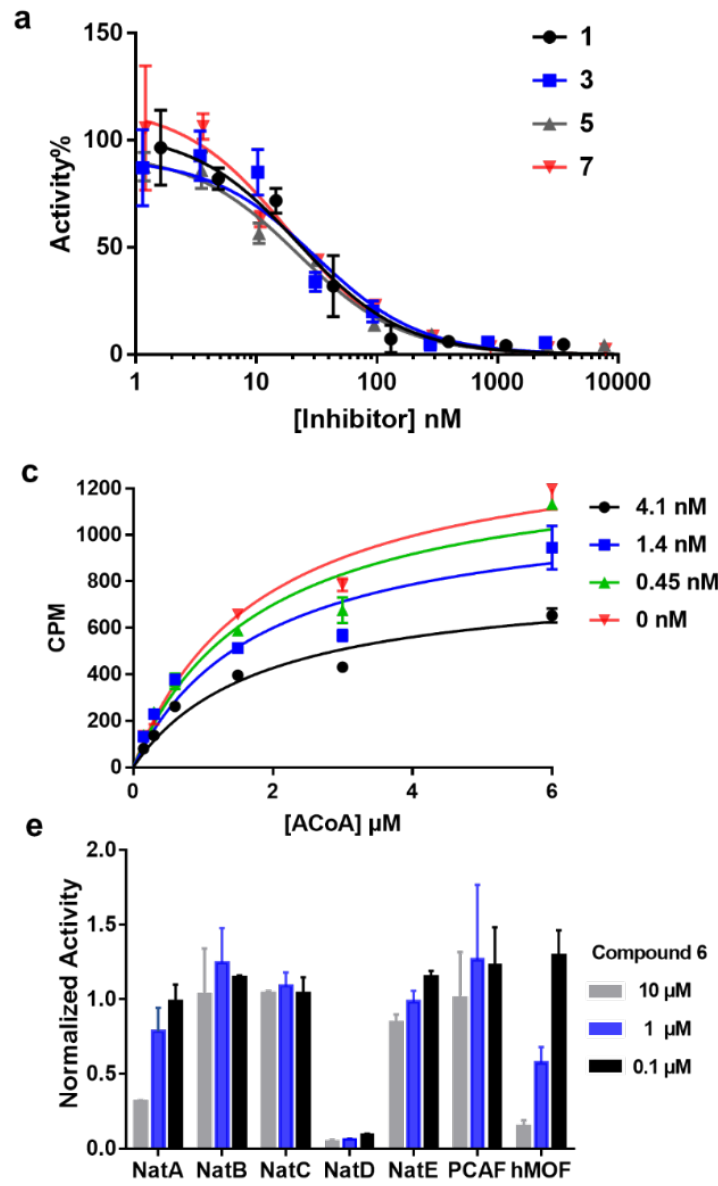
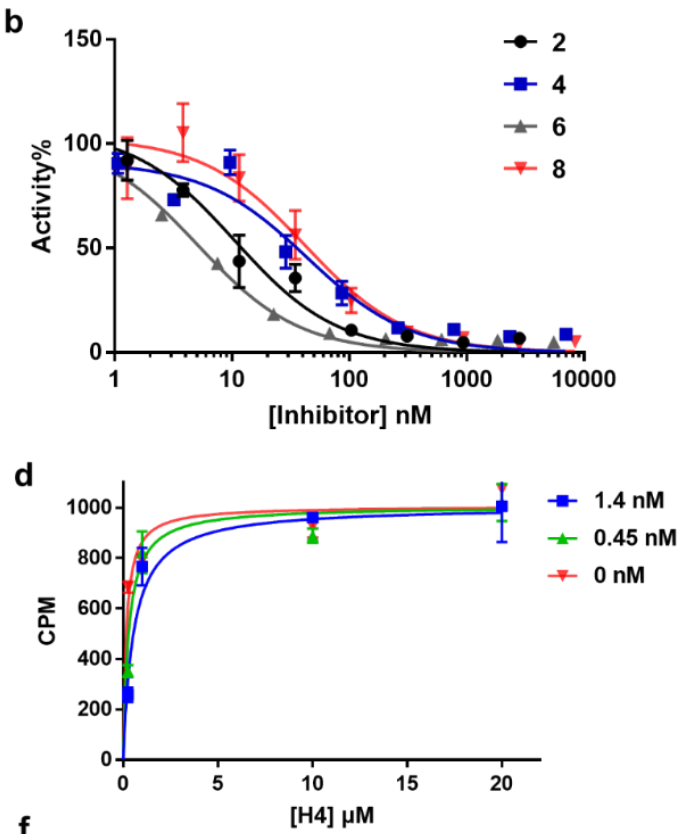

f

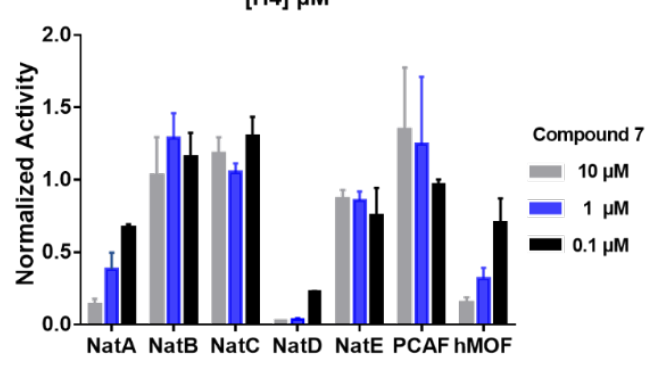

Figure 2. Biochemical characterization of bisubstrate analogues via the radioactive assay. a) Concentration-response plots of bisubstrate analogues with an acetyl linker under 4x $K_{\mathrm{m}}$ of H4-19 peptide and AcCoA condition fitted to Morrison's quadratic equation $(n=3)$. b) Concentration-response plots of bisubstrate analogues with a propionyl linker under $4 \mathrm{x} K_{\mathrm{m}}$ of H4-19 peptide and AcCoA condition (n=3). c) CoA-C3SGRGK (6) is noncompetitive with respect to AcCoA. d) 6 is competitive with respect to H4. e,f) Selectivity study 6 and 7 against a panel of protein acetyltransferases in triplicate $(n=3)$. 
Inhibition mechanism. The most potent compound $\mathbf{6}$ was selected to investigate the inhibition mechanism.

As shown in figure 2c, compound 6 exhibited a noncompetitive inhibition pattern with AcCoA. The data were globally fit to noncompetitive inhibition equation as a preferred model, producing the best fit parameters, $\alpha K_{\mathrm{i}}$ $=2.1 \pm 0.38 \mathrm{nM}$ and $K_{\mathrm{m}}=0.64 \pm 0.07 \mathrm{nM}$. In contrast, compound 6 exhibited a competitive inhibition pattern with peptide substrate (Figure 2d). The data were globally fit to competitive inhibition equation as a preferred model, producing the best fit parameters, $K_{\mathrm{i}}=0.61 \pm 0.22 \mathrm{nM}$ and $K_{\mathrm{m}}=0.16 \pm 0.03 \mathrm{nM}$. For a two substrate enzyme with an ordered binding mechanism where substrate A preferentially binds before substrate $\mathrm{B}$, it is expected that a bisubstrate analog will be competitive with substrate A and noncompetitive with substrate B ${ }^{25}$. Thus, our results suggested NatD undergoes an ordered Bi-Bi mechanism, in which the peptide substrate preferentially binds NatD first, followed by AcCoA.

Selectivity Study. Two of the most potent bisubstrate analogues 6 and 7 were chosen to examine their selectivity against a panel of closely-related $\mathrm{N}$-terminal acetyltransferases, including NatA, NatB, NatC, NatE; and protein lysine acetyltransferases PCAF and hMOF, which all harbor an Ac-CoA binding motif. Both 6 and 7 did not show any inhibition towards NatB, NatC, NatE, and PCAF at $10 \mu \mathrm{M}$ (Figure 2e,f), indicating over 10,000-fold selectivity for NatD. Compound 6 demonstrated $10-40 \%$ of inhibition against both NatA and $\mathrm{hMOF}$ at $1.0 \mu \mathrm{M}$, indicating over 1,000 fold selectivity for NatD over NatA and hMOF. 7 displayed $\mathrm{IC}_{50}$ values over $0.1 \mu \mathrm{M}$ against both NatA and hMOF, suggesting that it was less selective than 6. As NatA is a founding member of the NAT family that prefers to acetylate substrates starting with Ser or Ala, decreased selectivity of 7 compared to $\mathbf{6}$ is informative in the future development of selective NatD inhibitors.

Co-crystal Structures of 5 and 6 with NatD. To understand the molecular interactions between the bisubstrate inhibitors and NatD, the X-ray co-crystal structures of NatD complexed with 5 (PDB ID: 7KD7) and 6 (PDB ID: 7KPU) were obtained at $1.44 \AA$ and $1.43 \AA$ resolution, respectively (Figure 3a-b). The structure refinement statistics for these structures can be found in Table S1. Overall, both structures showed high similarity to the previously reported NatD/CoA/SGRGK ternary complex (PDB ID: 4U9W) ${ }^{8}$. Structural alignment of the 5-NatD and 6-NatD binary complexes with the NatD/CoA/SGRGK ternary complex gave 
RMSD values of $0.255 \AA$ and $0.217 \AA$, respectively. Interestingly, despite the different length of the linker region within the two bisubstrate inhibitors, the sulfur atom of the CoA and the nitrogen atom of the peptide $\mathrm{N} \alpha$-amino group remain in the same position (Figure 3c). Thus, such similar positioning of these two atoms explains the comparable potency of the inhibitors with two different linkers as described above. Also noteworthy is that CoA-C2-SGRGK and CoA-C3-SGRGK adopt slightly different CoA binding modes, especially with respect to the $\beta$-mercaptoethylamine group (Figure 3c). Thus, we speculate that the flexibility of this CoA binding region endows NatD the ability to accept a bisubstrate inhibitor CoA-C3-SGRGK with a relatively long linker. The structures also reveal why $\mathbf{9}$ and $\mathbf{1 0}$ poorly inhibit NatD, since both the peptide and CoA portion of the inhibitor make important contributions to inhibitor binding. The tight binding of bisubstrate analogues further supports the Bi-Bi mechanism of NatD.

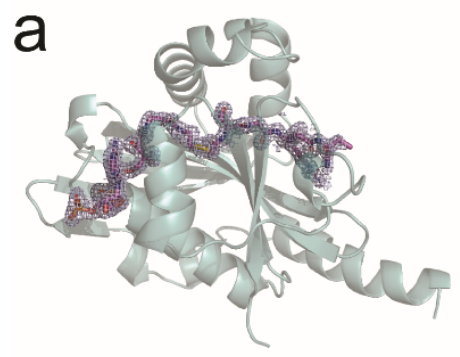

hNatD with COA-C2-SGRGK

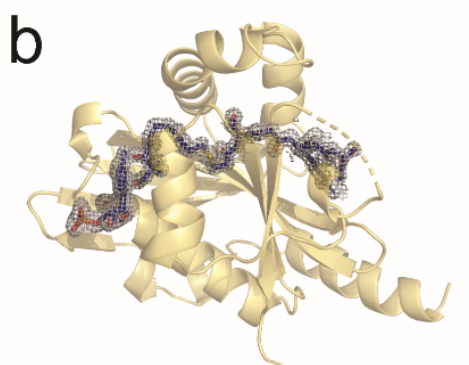

hNatD with COA-C3-SGRGK
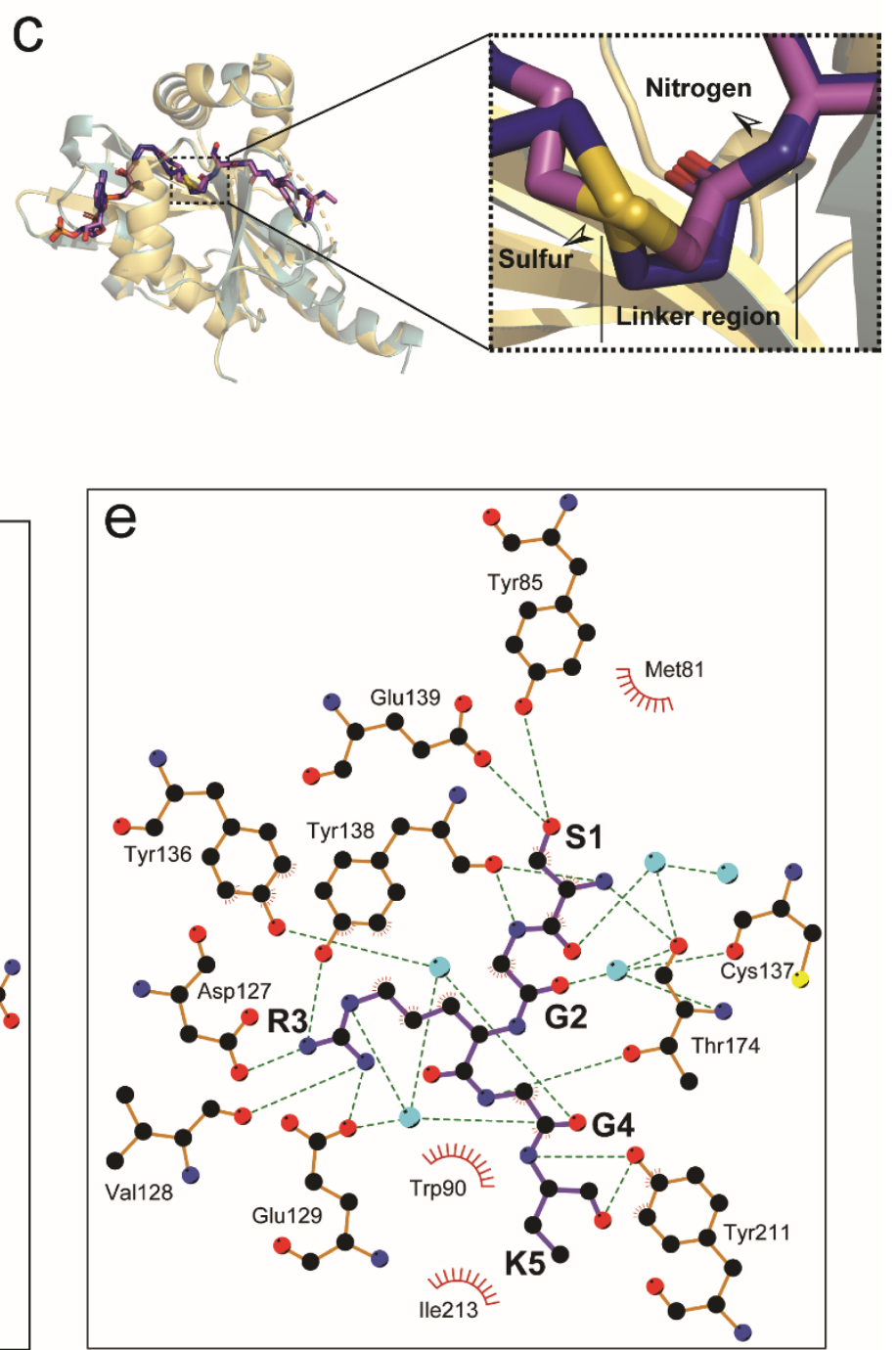

Figure 3. Structures of hNatD with Inhibitors. 
(a) Structure of hNatD with 5 (CoA-C2-SGRGK) bound. hNatD is shown in cyan as a cartoon and CoA-C2SGRGK as magenta sticks. The $2 \mathrm{mF}_{\mathrm{obs}}-\mathrm{DF}_{\mathrm{cal}}$ electron density around the bisubstrate is shown at a contour level of $1 \sigma$ (gray mesh).

(b) Structure of hNatD with 6 (CoA-C3-SGRGK) bound. hNatD is shown in yellow as a cartoon and CoAC3-SGRGK as blue sticks. The $2 \mathrm{mF}_{\text {obs }}-\mathrm{DF}_{\text {cal }}$ electron density around the bisubstrate is shown at a contour level of $1 \sigma$ (gray mesh).

(c) Overlay of the structure in (a) and (b). The zoom-in view shows the positions of the sulfur atom of CoA and the nitrogen of the peptide amino group.

(d) Interaction between CoA and hNatD residues is generated with LIGPLOT Hydrogen bonds are indicated by dashed green lines, and van der Waals interactions are indicated with red semicircles. Waters molecules are shown as cyan spheres.

(e) Interaction between SGRGK and hNatD residues is generated with LIGPLOT. Hydrogen bonds are indicated by dashed green lines, and van der Waals interactions are indicated with red semicircles. Waters molecules are shown as cyan spheres.

Given the similarity between both NatD/inhibitor structures, we focused on the structure of NatD with CoA-C2-Ser ${ }^{1}-\mathrm{Gly}^{2}-\mathrm{Arg}^{3}-\mathrm{Gly}^{4}-\mathrm{Lys}^{5}$ to further examine the molecular basis of NatD inhibition. An extensive H-bonding network is observed for CoA recognition involving several water molecules and NatD residues Asn80, Val140, Leu142, Val146, Arg148, Lys149, Gly150, Leu151, Gly152, Lys153, Phe176, and Asn179

(Figure 3d). Hydrophobic interactions are also observed from NatD residues Met81, Gln141, Arg 147, Leu173, Gly181, Ala182, Phe185, Phe186, and Ala189. These extensive interactions explain why inhibitory activity drops significantly when the CoA portion is removed (Table 1, compare 6 and 10). NatD interacts with the peptide portion of the bisubstrate inhibitor through hydrogen bonding to the backbone of residues 15, and the sidechains of $\operatorname{Ser}^{1}$ and $\mathrm{Arg}^{3}$. These interactions involve several water molecules and NatD residues Tyr85, Asp127, Val128, Glu129, Tyr136, Cys137, Tyr138, Gln139, Thr174, and Tyr121 (Figure 3e). In contrast, van der Waals interactions are significantly more limited, involving only several residues, including Met80, Trp90, Ile213. The extensive NatD interaction with the first three residues is consistent with the 
biochemical inhibitory results: inhibition potency depends on the inclusion of $\operatorname{Ser}^{1}$ through $\operatorname{Arg}^{3}$ (Table 1, compare 9 to 1-8). The NatD/inhibitor structures also reveal that the sidechain of $\mathrm{Lys}^{5}$ does not mediate any interactions with the enzyme, which is consistent with the biochemical findings that a minimal effect on inhibitor potency was observed when Lys $^{5}$ was replaced with Ala (Table 1, compare 3-4 to 5-6). Taking the structures together with the binding data, we propose that compounds that mimic at least the mercapto group of acetyl-CoA and the SGR sequence of the peptide with some toleration for flexibility linking these regions could represent suitable drug-like lead molecules for NatD inhibition.

Cellular Target Engagement. Although the inherent properties of bisubstrate inhibitors preclude their direct use in cellular studies as they are not be able to directly penetrate the cell membrane, we took advantage of digitonin permeabilization to promote cell uptake of compounds $\mathbf{2}$ and $\mathbf{6}$ for a preliminary investigation on cellular target engagement ${ }^{26}$. At $100 \mu \mathrm{M}$ of compounds 2 and $\mathbf{6}$ with $2 \mathrm{~h}$ incubation, we were able to introduce the compounds into digitonin $(5 \mu \mathrm{g} / \mathrm{mL})$ treated HCT116 cells (Figure S4) ${ }^{27}$. Although the amount of 2 and 6 that could enter cells could not be determined, both $\mathbf{2}$ and $\mathbf{6}$ induced a higher thermal stabilization $\left(\Delta T_{\mathrm{agg}}=\right.$ $+1.3{ }^{\circ} \mathrm{C}$ and $+1.7{ }^{\circ} \mathrm{C}$, respectively) using a cellular thermal shift assay (CETSA) compared to the control (Figure 4) ${ }^{28,29}$. This result demonstrated that $\mathbf{2}$ and $\mathbf{6}$ could engage NatD in cells. Future efforts will focus on the introduction of cell-permeable peptides at the C-terminal end of the bisubstrate inhibitors to improve the cell penetration, together with a comprehensive SAR of $\mathbf{6}$ for future optimization.

a

Temperature ${ }^{\circ} \mathrm{C}$

$\begin{array}{llllllllllll}37 & 40 & 45 & 50 & 55 & 58 & 60 & 62 & 65 & 69 & 73 & 75\end{array}$

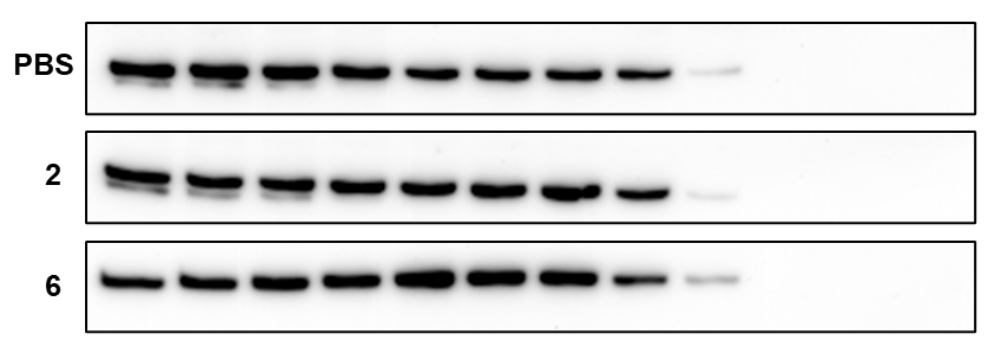

Anti-NatD b

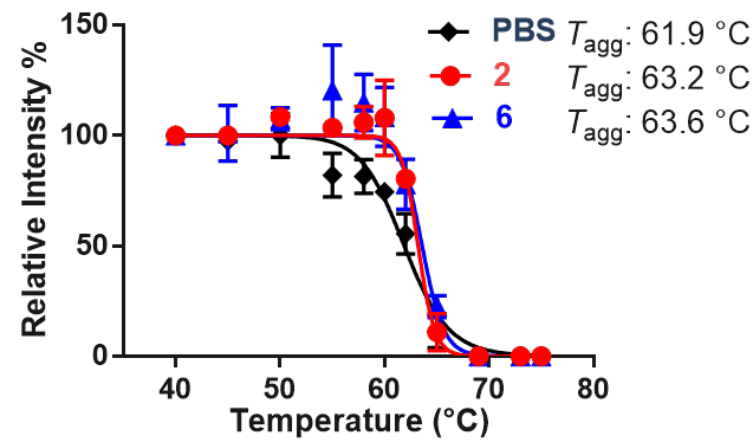

Figure 4. Cellular thermal shift assay. a) Thermal stability of endogenous NatD by immunoblot using anti-NatD antibody (Invitrogen PIPA520882) when treated with $\mathbf{2}$ or $\mathbf{6}$ or PBS buffer for $2 \mathrm{~h}$ at $100 \mu \mathrm{M}$ after 

made available under aCC-BY-NC-ND 4.0 International license.

digitonin $(5 \mu \mathrm{g} / \mathrm{mL})$ permeabilization for $20 \mathrm{~min}$. b) Quantified the relative NatD band intensities of the immunoblot in duplicates.

\section{CONCLUSION}

In this work, we designed and synthesized the first series of potent and selective NatD bisubstrate inhibitors 1-8, exhibiting $K_{\mathrm{i} \text {,app }}$ values ranging from $1.0-8.7 \mathrm{nM}$ in the radioactive assay. The most potent inhibitor CoAC3-SGRGK showed a $K_{\text {i,app }}$ of $1.0 \pm 0.11 \mathrm{nM}$, exhibiting about 1,000-fold selectivity for NatD over other acetyltransferases, including NatA-C, NatE, hMOF, and PCAF. Compared to reported bisubstrate inhibitors for other NATs, including NatA and NatE using a similar bisubstrate strategy ${ }^{20}$, the high potency of NatD bisubstrate inhibitors further establish the uniqueness of NatD and strengthen the possibility to develop potent and specific inhibitors for NatD. Furthermore, the co-crystal structures of NatD in complex with CoA-C3SGRGK and CoA-C2-SGR clearly demonstrate that the bisubstrate inhibitors engaged both substrate and cofactor AcCoA binding sites. The structural observations reveal that the NatD active site is specifically tailored for its histone substrate, explaining the selectivity of the NatD bisubstrate inhibitors. Comparable inhibitory activities and minor differences in the AcCoA binding site for bisubstrate analogues with either an acetyl or propionyl linker suggest active site plasticity, which may result from a subtle conformational change within the cofactor binding site of NatD. Moreover, these co-crystal structures of NatD-inhibitor binary complexes provide a structural foundation to guide the future development of drug-like NatD inhibitors.

\section{EXPERIMENTAL SECTION}

Chemistry General Procedures. All chemicals and solvents were purchased from commercial suppliers and used without further purification unless stated otherwise. Preparative high pressure liquid chromatography (RP-HPLC) was performed on an Agilent 1260 Series system. Systems were run with $0-95 \%$ methanol/water gradient with a $0.1 \%$ TFA modifier. High-resolution Matrix-assisted laser desorption/ionization (MALDI) spectra were performed on a 4800 MALDI TOF/TOF mass spectrometry (Sciex) at the Mass Spectrometry and Purdue Proteomics Facility (PPF), Purdue University. Peptides were synthesized on a CEM Liberty Blue 
peptide synthesizer. Compounds were also characterized and confirmed by TLC-MS or MALDI-MS. The purity of final compounds was confirmed on a Waters LC-MS system and/or Agilent 1260 Series system. Systems were run with $0-40 \%$ methanol/water gradient with $0.1 \%$ TFA. The purity of all target compounds showed $>95 \%$.

General procedure A for solid-phase peptide synthesis. The Peptides were synthesized using a Liberty Blue automated microwave peptide synthesizer (CEM Corp., Matthews, NC, USA) following a standard Fmoc protocol ${ }^{30}$. A Rink Amide MBHA resin $(0.05 \mathrm{mmol})$ was used as solid support and placed in the microwave tube. Standard couplings of amino acids were carried out at $0.2 \mathrm{M}$ in DMF and external amino acids at $0.1 \mathrm{M}$ in DMF using 0.5 M DIC and 1.0 M Oxyma in DMF for activation and 20\% piperidine in DMF for deprotection. The resin was transferred to a filter-equipped syringe, washed with $\mathrm{CH}_{2} \mathrm{Cl}_{2}(3 \mathrm{~mL})$ and $\mathrm{MeOH}$ $(3 \mathrm{~mL})$ three times, and dried under air.

General procedure B for the synthesis of bromoacetylated peptide. ${ }^{20}$ To a suspension of peptide on resin (0.05 mmol, 1.0 equiv) in DMF (2 mL) were added corresponding acid (0.1 mmol, 2 equiv), DIC (15.5 $\mu \mathrm{L}$, $0.1 \mathrm{mmol}, 2$ equiv), and HOBt (13.5 mg, $0.1 \mathrm{mmol}, 2$ equiv). The suspension was shaken at room temperature for $20 \mathrm{~h}$. The solvent was filtered, and the resulting resin was washed with $\mathrm{CH}_{2} \mathrm{Cl}_{2}(3 \mathrm{~mL})$ and $\mathrm{MeOH}(3 \mathrm{~mL})$ three times and dried under air. The dried peptide was cleaved from the resin using a cleavage cocktail $(\mathrm{TFA} / \mathrm{TIPS} / \mathrm{ddH} 2 \mathrm{O}=95 / 2.5 / 2.5 \mathrm{v} / \mathrm{v})(5 \mathrm{~mL})$ for $0.05 \mathrm{mmol}$ scale of resin for $4 \mathrm{~h}$. The suspension was filtered, washed with TFA $(2 \mathrm{~mL})$ and the volatiles of the filtrate was removed under $\mathrm{N}_{2}$. The peptide solution was precipitated with cold anhydrous ether $(10 \mathrm{~mL})$, centrifuged at $4200 \mathrm{rpm}$ for $10 \mathrm{~min}$. The supernatant was discarded, and the pellet was washed with cold ether, centrifuged, removed supernatant, and air-dried. The dried peptide was dissolved in $\mathrm{ddH} 2 \mathrm{O}(5 \mathrm{~mL})$ and filtered through a $0.2 \mu \mathrm{M}$ filter membrane. The filtered sample solution was purified by preparative reversed-phase high performance liquid chromatography (RPHPLC) using an Agilent 1260 Series system with a C18 column $(5 \mu \mathrm{m}, 10 \mathrm{~mm} \times 250 \mathrm{~mm})$ at a flow rate of $4.0 \mathrm{~mL} / \mathrm{min}$. Two mobile phases (mobile phase A consisting of $0.1 \%$ trifluoroacetic acid in ddH2O; mobile phase B consisting of methanol) were used and monitored at 214 and $256 \mathrm{~nm}$. An injection volume of $400 \mu \mathrm{L}$ of the solution was injected into the column. The desired fractions were evaporated, and the resulting solution was frozen $\left(-85^{\circ} \mathrm{C}\right)$ and lyophilized. 
General procedure $\mathbf{C}$ for synthesis of the bisubstrate analogues ${ }^{20}$. The bromoacetylated peptide (1 equiv) was dissolved in $1 \mathrm{~mL}$ triethylammonium bicarbonate buffer, $\mathrm{pH} 8.4 \pm 0.1$. The mixture was added with coenzyme A trilithium salt dihydrate ( 2 equiv), and the solution was allowed to react for $4 \mathrm{~h}$ at room temperature and then overnight at $4{ }^{\circ} \mathrm{C} .100 \mathrm{uL}$ of the reaction solution was purified by HPLC to obtain the desired product, which was detected by MALDI.

Compound 1 ( $5.1 \mathrm{mg}, 43 \%$ yield) was synthesized by following the general procedure $\mathrm{C}$ as a foamy white solid. MALDI-TOF (positive) $m / z$ : calcd for $\mathrm{C}_{36} \mathrm{H}_{63} \mathrm{~N}_{15} \mathrm{O}_{22} \mathrm{P}_{3} \mathrm{~S}^{+}[\mathrm{M}+\mathrm{H}]^{+} m / z$ 1182.3200, found $m / z$ 1182.3802. Compound 2 ( $4.3 \mathrm{mg}, 36 \%$ yield) was synthesized by following the general procedure $\mathrm{C}$ as a foamy white solid. MALDI-TOF (positive) $m / z$ : calcd for $\mathrm{C}_{37} \mathrm{H}_{65} \mathrm{~N}_{15} \mathrm{O}_{22} \mathrm{P}_{3} \mathrm{~S}^{+}[\mathrm{M}+\mathrm{H}]^{+} m / z$ 1196.3357, found $m / z$ 1196.3724. Compound 3 ( $5.6 \mathrm{mg}, 45 \%$ yield) was synthesized by following the general procedure $\mathrm{C}$ as a foamy white solid. MALDI-TOF (positive) $m / z$ : calcd for $\mathrm{C}_{39} \mathrm{H}_{68} \mathrm{~N}_{16} \mathrm{O}_{23} \mathrm{P}_{3} \mathrm{~S}^{+}[\mathrm{M}+\mathrm{H}]^{+} m / z$ 1253.3571, found $m / z$ 1253.3676. Compound 4 ( $4.8 \mathrm{mg}, 38 \%$ yield) was synthesized by following the general procedure $\mathrm{C}$ as a foamy white solid. MALDI-TOF (positive) $m / z$ : calcd for $\mathrm{C}_{40} \mathrm{H}_{70} \mathrm{~N}_{16} \mathrm{O}_{23} \mathrm{P}_{3} \mathrm{~S}^{+}[\mathrm{M}+\mathrm{H}]^{+} m / z$ 1267.3728, found $m / z$ 1267.4188. Compound 5 (6.2 $\mathrm{mg}, 47 \%$ yield) was synthesized by following the general procedure $\mathrm{C}$ as a foamy white solid. MALDI-TOF (positive) $m / z$ : calcd for $\mathrm{C}_{42} \mathrm{H}_{75} \mathrm{~N}_{17} \mathrm{O}_{23} \mathrm{P}_{3} \mathrm{~S}^{+}[\mathrm{M}+\mathrm{H}]^{+} m / z$ 1310.4150, found $m / z$ 1310.4417. Compound 6 (4.8 mg, 36\% yield) was synthesized by following the general procedure C as a foamy white solid. MALDI-TOF (positive) $m / z$ : calcd for $\mathrm{C}_{43} \mathrm{H}_{77} \mathrm{~N}_{17} \mathrm{O}_{23} \mathrm{P}_{3} \mathrm{~S}^{+}[\mathrm{M}+\mathrm{H}]^{+} m / z$ 1324.4306, found $m / z$ 1324.4221. Compound 7 (4.7 $\mathrm{mg}, 42 \%$ yield) was synthesized by following the general procedure $\mathrm{C}$ as a foamy white solid. MALDI-TOF (positive) $m / z$ : calcd for $\mathrm{C}_{34} \mathrm{H}_{60} \mathrm{~N}_{14} \mathrm{O}_{23} \mathrm{P}_{3} \mathrm{~S}^{+}[\mathrm{M}+\mathrm{H}]^{+} m / z$ 1125.2986, found $m / z$ 1125.2793. Compound 8 (3.8 mg, 33\% yield) was synthesized by following the general procedure $\mathrm{C}$ as a foamy white solid. MALDI-TOF (positive) $m / z$ : calcd for $\mathrm{C}_{35} \mathrm{H}_{62} \mathrm{~N}_{14} \mathrm{O}_{23} \mathrm{P}_{3} \mathrm{~S}^{+}[\mathrm{M}+\mathrm{H}]^{+} m / z$ 1139.3142, found $m / z$ 1139.2950. Compound 9 (4.7 mg, 51\% yield) was synthesized by following the general procedure $\mathrm{C}$ as a foamy white solid. MALDI-TOF (positive) $m / z$ : calcd for $\mathrm{C}_{26} \mathrm{H}_{45} \mathrm{~N}_{9} \mathrm{O}_{19} \mathrm{P}_{3} \mathrm{~S}^{+}[\mathrm{M}+\mathrm{H}]^{+} m / z$ 912.1760, found $m / z$ 912.1606. Compound 10 ( $3.1 \mathrm{mg}, 55 \%$ yield) was synthesized by following the general procedure B as a foamy white solid. MALDI-TOF (positive) $m / z$ : calcd for $\mathrm{C}_{22} \mathrm{H}_{43} \mathrm{~N}_{10} \mathrm{O}_{7}^{+}[\mathrm{M}+\mathrm{H}]^{+} m / z$ 559.3311, found $m / z 559.3316$.

\section{Protein Expression and Purification.}


Expression and purification of human PCAF, hMOF, NatA-E except for NatC, were performed as previously described ${ }^{8,17,31-34}$.

NatC: Ternary S. pombe NatC encoding NAA30 ${ }^{\mathrm{FL}}$, NAA35 $31-708$, and NAA38 $48-116$, was expressed in E. coli cells, and purified as follows. Cells were harvested by centrifugation, resuspended, and lysed by sonication in lysis buffer containing $25 \mathrm{mM}$ Tris, $\mathrm{pH} \quad 8.0, \quad 300 \mathrm{mM} \quad \mathrm{NaCl}, \quad 10 \mathrm{mg} / \mathrm{mL} \quad$ PMSF (phenylmethanesulfonylfluoride). The lysate was clarified by centrifugation and passed over a nickel resin (Thermo Scientific), which was subsequently washed with $\sim 10$ column volumes of wash buffer containing 25 $\mathrm{mM}$ Tris, $\mathrm{pH}$ 8.0, $300 \mathrm{mM} \mathrm{NaCl}, 20 \mathrm{mM}$ imidazole, $10 \mathrm{mM}$ 2-mercaptoethanol. The protein was eluted with buffer containing $25 \mathrm{mM}$ Tris, $\mathrm{pH}$ 8.0, $300 \mathrm{mM} \mathrm{NaCl}, 200 \mathrm{mM}$ imidazole, $10 \mathrm{mM} \beta \mathrm{ME}$. After elution, Histagged Ulp1 protease was added to the eluent to cleave the SUMO tag. The eluent was further dialyzed into a buffer containing $25 \mathrm{mM}$ sodium citrate monobasic, $\mathrm{pH} 5.5,10 \mathrm{mM} \mathrm{NaCl}$ and $10 \mathrm{mM}$ 2-mercaptoethanol. Protein was purified with a 5-mL HiTrap SP ion-exchange column and eluted with a salt gradient (10-1000 $\mathrm{mM} \mathrm{NaCl}$ ). Peak fractions were concentrated to $\sim 0.5 \mathrm{~mL}$ with a $50 \mathrm{kDa}$ concentrator (Amicon Ultra, Millipore), and loaded onto an S200 gel-filtration column (GE Healthcare) in a buffer containing $25 \mathrm{mM}$ HEPES, pH 7.0, $200 \mathrm{mM} \mathrm{NaCl}, 1 \mathrm{mM}$ dithiothreitol (DTT). Peak fractions were concentrated to $\sim 15 \mathrm{mg} / \mathrm{mL}$ as measured by UV280 and flash-frozen for storage at $-80{ }^{\circ} \mathrm{C}$ until use.

Fluorescence Assays. A fluorescence-based assay was applied to study the $\mathrm{IC}_{50}$ values for all the compounds. The assay was performed under the following conditions in a final well volume of $40 \mu \mathrm{L}: 25 \mathrm{mM}$ HEPES (pH = 7.5), $150 \mathrm{mM} \mathrm{NaCl}, 0.01 \%$ Triton $\mathrm{X}-100,0.05 \mu \mathrm{M}$ NatD, $0.5 \mu \mathrm{M}$ AcCoA, and $15 \mu \mathrm{M}$ ThioGlo4. The inhibitors were added at concentrations ranging from $0.15 \mathrm{nM}$ to $10 \mu \mathrm{M}$. After $30 \mathrm{~min}$ incubation, reactions were initiated by the addition of 5.0 $\mu \mathrm{M}$ H4-8 peptide. Fluorescence was monitored on a BMG ClariOtar microplate reader with excitation $400 \mathrm{~nm}$ and emission $465 \mathrm{~nm}$. Data were processed by using GraphPad Prism software 7.0.

Radioisotopic Acetyltransferase Assay. FL NatD was used for activity assays. NatD Acetyltransferase assays were carried out in $25 \mathrm{mM}$ HEPES, $\mathrm{pH}$ 7.5, $150 \mathrm{mM} \mathrm{NaCl}$, and $1 \mathrm{mM}$ DTT. The H4 substrate peptide 
used in the assay corresponds to the first 19 residues of human $\mathrm{H} 4\left(\mathrm{NH}_{2}\right.$-SGRGKGGKGLGKGGAKRHR$\mathrm{COOH}$; GenScript). In the assay, $50 \mathrm{nM}$ of hNatD was mixed with $2 \mu \mathrm{M}$ of radiolabeled $\left[{ }^{14} \mathrm{C}\right]$ acetyl-CoA $(4$ $\mathrm{mCi} / \mathrm{mmol}$; PerkinElmer Life Sciences), $20 \mu \mathrm{M}$ of the peptide, and inhibitors of concentrations ranging from $0.15 \mathrm{nM}$ to $10 \mu \mathrm{M}$, for a reaction of 30 minutes at room temperature. To quench the reaction, the reaction solution was applied onto negatively charged P81 paper disks (SVI, St vincent's institute medical research) to trap the peptides, and the paper disks were immediately placed in wash buffer (10 mM HEPES, pH 7.5). The paper disks were washed three times, at 5 minutes per wash, to remove unreacted acetyl-CoA. The papers were then dried with acetone and added to $4 \mathrm{~mL}$ of scintillation fluid, and the signal was measured with a Packard Tri-Carb 1500 liquid scintillation analyzer. Each reaction was performed in triplicate. $\mathrm{IC}_{50}$ statistic values were determined with GraphPad Prism software $7.0^{8}$.

Inhibition Mechanism Study. The experiment procedures are the same as described for the radioactive assay. In the AcCoA concentration fixed assay, $50 \mathrm{nM}$ of $\mathrm{hNatD}$ was mixed with $2 \mu \mathrm{M}$ of radiolabeled $\left[{ }^{14} \mathrm{C}\right]$ acetylCoA, the $\mathrm{H} 4$ peptide $(0.25,1.0,10$ and $20 \mu \mathrm{M})$, and inhibitors $(0,0.45$ and $1.4 \mathrm{nM})$, for a reaction of 30 minutes at room temperature. In the $\mathrm{H} 4$ peptide concentration fixed assay, $50 \mathrm{nM}$ of $\mathrm{hNatD}$ was mixed with $20 \mu \mathrm{M}$ of $\mathrm{H} 4$ peptide, the $\left[{ }^{14} \mathrm{C}\right]$ acetyl-CoA $(0.15,0.3,0.6,1.5,3$ and $6 \mu \mathrm{M})$, and inhibitors $(0,0.45,1.4$ and 4.1 $\mathrm{nM})$, for a reaction of 13 minutes at room temperature.

Selectivity Assays. The selectivity studies of NatA, NatB, NatC, NatE, PCAF, and hMOF were performed as follows. $100 \mathrm{nM}$ of hNatA was mixed with $30 \mu \mathrm{M}$ of $\left[{ }^{14} \mathrm{C}\right]$ acetyl-CoA and $30 \mu \mathrm{M}$ of either $\mathrm{H} 4$ peptide or SASE peptide ( $\mathrm{NH}_{2}$-SASEAGVRWGRPVGRRRRP-COOH; GenScript), with none, $0.1 \mu \mathrm{M}, 1 \mu \mathrm{M}$ or $10 \mu \mathrm{M}$ of inhibitors, for a 12-minute reaction at room temperature, in the buffer containing $75 \mathrm{mM} \mathrm{HEPES,} \mathrm{pH}$ 7.5, $120 \mathrm{mM} \mathrm{NaCl}, 1 \mathrm{mM}$ DTT.

$100 \mathrm{nM}$ of hNatB was mixed with $50 \mu \mathrm{M}\left[{ }^{14} \mathrm{C}\right]$ acetyl-CoA and $50 \mu \mathrm{M}$ of $\mathrm{MDVF}$ peptide $\left(\mathrm{NH}_{2}-\right.$ MDVFMKGRWGRPVGRRRRP-COOH, GenScript), with none, $0.1 \mu \mathrm{M}, 1 \mu \mathrm{M}$ or $10 \mu \mathrm{M}$ of inhibitors, for a 10-minute reaction at room temperature, in the buffer containing $75 \mathrm{mM}$ HEPES, $\mathrm{pH} 7.5,120 \mathrm{mM} \mathrm{NaCl}, 1$ mM DTT. 

made available under aCC-BY-NC-ND 4.0 International license.

$50 \mathrm{nM}$ of $\mathrm{SpNatC}$ was mixed with $30 \mu \mathrm{M}\left[{ }^{14} \mathrm{C}\right]$ acetyl-CoA and $10 \mu \mathrm{M}$ of MLRF peptide $\left(\mathrm{NH}_{2}-\mathrm{ML}\right.$ RFVTKRWGRPVGRRRRPCOOH, GenScript), with none, $0.1 \mu \mathrm{M}, 1 \mu \mathrm{M}$ or $10 \mu \mathrm{M}$ of inhibitors, for a 5minute reaction at room temperature, in the buffer containing $75 \mathrm{mM}$ HEPES, $\mathrm{pH} 7.0,120 \mathrm{mM} \mathrm{NaCl}, 1 \mathrm{mM}$ DTT.

$300 \mathrm{nM}$ of hNatE was mixed with $50 \mu \mathrm{M}\left[{ }^{14} \mathrm{C}\right]$ acetyl-CoA and $100 \mu \mathrm{M}$ of MLGP peptide $\left(\mathrm{NH}_{2}-\right.$ MLGPEGGRWGRPVGRRRRP-COOH, GenScript), with none, $0.1 \mu \mathrm{M}, 1 \mu \mathrm{M}$ or $10 \mu \mathrm{M}$ of inhibitors, for a 40-minute reaction at room temperature, in the buffer containing $75 \mathrm{mM}$ HEPES, $\mathrm{pH} 7.0,120 \mathrm{mM} \mathrm{NaCl}, 1$ mM DTT.

$100 \mathrm{nM}$ of PCAF was mixed with $50 \mu \mathrm{M}\left[{ }^{14} \mathrm{C}\right]$ acetyl-CoA and $400 \mu \mathrm{M}$ of H4 peptide, with none, $0.1 \mu \mathrm{M}, 1$ $\mu \mathrm{M}$ or $10 \mu \mathrm{M}$ of inhibitors, for a 20 -min reaction at room temperature, in the buffer containing $40 \mathrm{mM}$ Tris, $\mathrm{pH} 8.0,100 \mathrm{mM} \mathrm{NaCl}, 1 \mathrm{mM}$ DTT and $2 \mathrm{mg} / \mathrm{mL}$ BSA.

$50 \mathrm{nM}$ of hMOF was mixed with $50 \mu \mathrm{M}\left[{ }^{14} \mathrm{C}\right]$ acetyl-CoA and $400 \mu \mathrm{M}$ of $\mathrm{H} 4$ peptide, with none, $0.1 \mu \mathrm{M}, 1$ $\mu \mathrm{M}$ or $10 \mu \mathrm{M}$ of inhibitors, for a 20 -min reaction at room temperature, in the buffer containing $100 \mathrm{mM}$ Tris, pH 8.0, $50 \mathrm{mM} \mathrm{NaCl}, 1 \mathrm{mM}$ DTT, $800 \mu \mathrm{M}$ cysteine and $0.25 \mathrm{mg} / \mathrm{mL}$ BSA.

Co-crystallization and Structure Determination. For co-crystallization and structure determination of 5 and 6 with NatD, a truncation construct of $\mathrm{hNatD}^{17-220}$ was used and purified similarly as described above. 10 $\mathrm{mg} / \mathrm{mL}$ of purified $\mathrm{hNatD}^{17-220}$ was incubated with $1 \mathrm{mM}$ of either 5 or $\mathbf{6}$ for 30 minutes in ice before the crystal setup. The best crystals of $\mathrm{hNatD}^{17-220}$ with $\mathbf{5}$ bound was obtained with hanging-drop vapor diffusion at $20{ }^{\circ} \mathrm{C}$ in a well containing $0.1 \mathrm{M}$ Bis-Tris, $\mathrm{pH}$ 5.5, $2 \mathrm{M}$ Ammonium sulfate, in a drop containing a 1:1.5 mixture of protein to a well solution. The best crystals of $\mathrm{hNatD}^{17-220}$ with 6 bound was obtained with hangingdrop vapor diffusion at $20^{\circ} \mathrm{C}$ in a well solution containing $0.1 \mathrm{M}$ Bis-Tris, $\mathrm{pH}$ 5.5, $2 \mathrm{M}$ Ammonium sulfate, in a drop containing a $1.25: 1$ mixture of protein to a well solution. All crystals were cryoprotected by transferring them to their respective well solutions supplemented with $20 \%$ glycerol before being flash frozen 
in liquid nitrogen. Data were collected at the Advanced Photon Source (beamline 24-ID-E) and processed using HKL2000 ${ }^{35}$.

Structure Determination and Refinement. Both structures were determined by molecular replacement using the structure of NatD/CoA/SGRGK (PDB: 4U9W) with ligands and solvent molecules removed from the search model. Molecular replacement was done using Phaser in Phenix ${ }^{36}$. Initial Manual model building was done in Coot ${ }^{37}$ and all subsequent rounds of refinement were performed using Phenix refine and Coot interchangeably. Refinement statistics can be found in Table S1. The final model and structure factors were submitted to the Protein Data Bank. Distance calculations, as well as three-dimensional alignment r.m.s. deviations and graphics were generated in PyMOL (http://www.pymol.org/).

Cellular thermal shift assay. The assay was performed based on a modified protocol for the cell lysate CETSA experiments ${ }^{28}$. In brief, cultured HCT116 cells $\left(5.0 \times 10^{7}\right)$ was incubated with $5 \mu \mathrm{g} / \mathrm{mL}$ digitonin at $37{ }^{\circ} \mathrm{C}$ for $20 \mathrm{~min}^{26}$. The medium was aspirated and replenished with fresh medium with PBS or Inhibitors at $100 \mu \mathrm{M}$. After $2 \mathrm{~h}$, the cells were harvested and washed with PBS and resuspended in $1 \mathrm{~mL}$ of PBS. $300 \mu \mathrm{L}$ of the cells solution were directly lysed by three freeze-thaw cycles with liquid nitrogen and clarified by centrifugation at $20,000 \mathrm{~g}$ for $20 \mathrm{~min}$ at $4{ }^{\circ} \mathrm{C}$. The supernatant was analyzed with MALDI-MS. Aliquots of 50 $\mu \mathrm{L}$ from each condition were distributed into PCR strip tubes and heated at 37, 40, 45, 50, 55, 58, 60, 62, 65, 69,73 , and $75^{\circ} \mathrm{C}$ for $3 \mathrm{~min}$ before being cooled to room temperature for $3 \mathrm{~min}$. The cells were lysed by three freeze-thaw cycles with liquid nitrogen and clarified by centrifugation at $20,000 \mathrm{~g}$ for $20 \mathrm{~min}$ at $4{ }^{\circ} \mathrm{C}$. The soluble fractions (lysate) were then analyzed by immunoblotting using anti-NatD antibody (Invitrogen PIPA520882) and quantified using ImageJ ${ }^{29}$.

\section{ASSOCIATED CONTENT}

\section{Supporting Information}

The Supporting Information is available free of charge on the ACS Publications website. 
Figure S1-2. and HPLC spectra of compounds 1-10; Figure S3. IC 50 fitting curves of compounds; Figure S4.

Cell permeability study; Table S1.Data statistics for NatD crystal structures in complex with inhibitors. Molecular formula strings for all synthesized inhibitors.

\section{Accession Codes}

The coordinates for the structure of human NatD in complex with compound 5 (PDB ID: 7KD7) and 6 (PDB

ID: 7KPU) have been deposited in the Protein Data Bank. Authors will release the atomic coordinates and experimental data upon article publication.

\section{Author Information}

Corresponding Author

*Phone: (765) 494 3426. E-mail: huang-r@purdue.edu

\section{ORCID}

Rong Huang: 0000-0002-1477-3165

Ronen Marmorstein: 0000-0003-4373-4752

\section{Author Contributions}

Y.D. synthesized and characterized all compounds described in the manuscript. Y.H. and Y.D. performed fluorescence assay. Z.H. contributed to the synthesis. Y.D. and S.D. prepared manuscript figures and text. S.D. performed the radioactivity assay and obtained the co-crystal structures. S.D. and S.M.G. performed the selectivity study. R.M. designed and supervised experiments by S.D. and S.M.G. and prepared manuscript text. R.H. developed the concept, designed and supervised experiments by Y.D., Y.H., and Z.H., and prepared manuscript text and figures. All authors have read and approved the final version of the manuscript.

Notes

The authors declare no competing financial interest. 


\section{ACKNOWLEDGMENT}

The authors acknowledge the support from NIH grant R35GM118090 (RM) and proteomics core facility at

Purdue University Center for Cancer Research (P30 CA023168). We also thank the support from the Department of Medicinal Chemistry and Molecular Pharmacology $(\mathrm{RH})$ and Leah Gottlieb for her assistance in obtaining proteins of PCAF and hMOF for the inhibitor selectivity studies.

\section{ABBREVIATIONS}

NatA, protein N-terminal acetyltransferase A; CoA, coenzyme A; AcCoA, acetyl coenzyme A; rt, room temperature; TFA, trifluoroacetic acid.

\section{REFERENCES}

(1) Arnesen, T.; Van Damme, P.; Polevoda, B.; Helsens, K.; Evjenth, R.; Colaert, N.; Varhaug, J. E.; Vandekerckhove, J.; Lillehaug, J. R.; Sherman, F.; Gevaert, K. Proteomics Analyses Reveal the Evolutionary Conservation and Divergence of N-Terminal Acetyltransferases from Yeast and Humans. Proc. Natl. Acad. Sci. U. S. A. 2009, 106, 8157-8162.

(2) Scott, D. C.; Monda, J. K.; Bennett, E. J.; Harper, J. W.; Schulman, B. A. N-Terminal Acetylation Acts as an Avidity Enhancer within an Interconnected Multiprotein Complex. Science 2011, 334, 674-678.

(3) Behnia, R.; Panic, B.; Whyte, J. R. C.; Munro, S. Targeting of the Arf-like GTPase Arl3p to the Golgi Requires N-Terminal Acetylation and the Membrane Protein Sys1p. Nat. Cell Biol. 2004, 6, 405-413.

(4) Aksnes, H.; Ree, R.; Arnesen, T. Co-Translational, Post-Translational, and Non-Catalytic Roles of NTerminal Acetyltransferases. Molecular Cell. 2019, 73, 1097-1114.

(5) Deng, S.; Marmorstein, R. Protein N-Terminal Acetylation: Structural Basis, Mechanism, Versatility, and Regulation. Trends in Biochemical Sciences. 2021, 46, 15-27 .

(6) Ree, R.; Varland, S.; Arnesen, T. Spotlight on Protein N-Terminal Acetylation. Experimental and 
bioRxiv preprint doi: https://doi.org/10.1101/2021.01.24.427995; this version posted June 3, 2021. The copyright holder for this preprint (which was not certified by peer review) is the author/funder, who has granted bioRxiv a license to display the preprint in perpetuity. It is made available under aCC-BY-NC-ND 4.0 International license.

Molecular Medicine. 2018, 50, 1-13.

(7) Hole, K.; van Damme, P.; Dalva, M.; Aksnes, H.; Glomnes, N.; Varhaug, J. E.; Lillehaug, J. R.; Gevaert, K.; Arnesen, T. The Human N-Alpha-Acetyltransferase 40 (HNaa40p/HNatD) Is Conserved from Yeast and N-Terminally Acetylates Histones H2A and H4. PLoS One 2011, 6, e24713.

(8) Magin, R. S.; Liszczak, G. P.; Marmorstein, R. The Molecular Basis for Histone H4- and H2ASpecific Amino-Terminal Acetylation by NatD. Structure 2015, 23, 332-341.

(9) Polevoda, B.; Norbeck, J.; Takakura, H.; Blomberg, A.; Sherman, F. Identification and Specificities of N-Terminal Acetyltransferases from Saccharomyces Cerevisiae. EMBO J. 1999, 18, 6155-6168.

(10) Pavlou, D.; Kirmizis, A. Depletion of Histone N-Terminal-Acetyltransferase Naa40 Induces P53Independent Apoptosis in Colorectal Cancer Cells via the Mitochondrial Pathway. Apoptosis 2016, 21, 298-311.

(11) Liu, Z.; Liu, Y.; Wang, H.; Ge, X.; Jin, Q.; Ding, G.; Hu, Y.; Zhou, B.; Chen, Z.; Ge, X.; Zhang, B.; Man, X.; Zhai, Q. Patt1, a Novel Protein Acetyltransferase That Is Highly Expressed in Liver and Downregulated in Hepatocellular Carcinoma, Enhances Apoptosis of Hepatoma Cells. Int. J. Biochem. Cell Biol. 2009, 41, 2528-2537.

(12) Schiza, V.; Molina-Serrano, D.; Kyriakou, D.; Hadjiantoniou, A.; Kirmizis, A. N-Alpha-Terminal Acetylation of Histone H4 Regulates Arginine Methylation and Ribosomal DNA Silencing. PLoS Genet. 2013, 9, e1003805.

(13) Ju, J.; Chen, A.; Deng, Y.; Liu, M.; Wang, Y.; Wang, Y.; Nie, M.; Wang, C.; Ding, H.; Yao, B.; Gui, T.; Li, X.; Xu, Z.; Ma, C.; Song, Y.; Kvansakul, M.; Zen, K.; Zhang, C. Y.; Luo, C.; Fang, M.; Huang, D. C. S.; Allis, C. D.; Tan, R.; Zeng, C. K.; Wei, J.; Zhao, Q. NatD Promotes Lung Cancer Progression by Preventing Histone H4 Serine Phosphorylation to Activate Slug Expression. Nat. Commun. 2017, 8, 1-14.

(14) Liszczak, G.; Goldberg, J. M.; Foyn, H.; Petersson, E. J.; Arnesen, T.; Marmorstein, R. Molecular Basis for N-Terminal Acetylation by the Heterodimeric NatA Complex. Nat. Struct. Mol. Biol. 
bioRxiv preprint doi: https://doi.org/10.1101/2021.01.24.427995; this version posted June 3, 2021. The copyright holder for this preprint (which was not certified by peer review) is the author/funder, who has granted bioRxiv a license to display the preprint in perpetuity. It is made available under aCC-BY-NC-ND 4.0 International license.

2013, 20, 1098.

(15) Evjenth, R. H.; Brenner, A. K.; Thompson, P. R.; Arnesen, T.; Frøystein, N. Å.; Lillehaug, J. R. Human Protein N-Terminal Acetyltransferase HNaa50p (HNAT5/HSAN) Follows Ordered Sequential Catalytic Mechanism: Combined Kinetic and NMR Study. J. Biol. Chem. 2012, 287, 10081-10088.

(16) Weyer, F. A.; Gumiero, A.; Lapouge, K.; Bange, G.; Kopp, J.; Sinning, I. Structural Basis of HypK Regulating N-Terminal Acetylation by the NatA Complex. Nat. Commun. 2017, 8, 1-10.

(17) Deng, S.; Pan, B.; Gottlieb, L.; Petersson, E. J.; Marmorstein, R. Molecular Basis for N-Terminal Alpha-Synuclein Acetylation by Human Natb. Elife 2020, 9, e57491.

(18) Støve, S. I. I.; Magin, R. S. S.; Foyn, H.; Haug, B. E. E.; Marmorstein, R.; Arnesen, T. Crystal Structure of the Golgi-Associated Human Na-Acetyltransferase 60 Reveals the Molecular Determinants for Substrate-Specific Acetylation. Structure 2016, 24, 1044-1056.

(19) Goris, M.; Magin, R. S.; Foyn, H.; Myklebust, L. M.; Varland, S.; Ree, R.; Drazic, A.; Bhambra, P.; Støve, S. I.; Baumann, M.; Haug, B. E.; Marmorstein, R.; Arnesen, T. Structural Determinants and Cellular Environment Define Processed Actin as the Sole Substrate of the N-Terminal Acetyltransferase NAA80. Proc. Natl. Acad. Sci. U. S. A. 2018, 115, 4405-4410.

(20) Foyn, H.; Jones, J. E.; Lewallen, D.; Narawane, R.; Varhaug, J. E.; Thompson, P. R.; Arnesen, T. Design, Synthesis, and Kinetic Characterization of Protein N-Terminal Acetyltransferase Inhibitors. ACS Chem. Biol. 2013, 8 (6), 1121-1127.

(21) Chen, D.; Dong, G.; Noinaj, N.; Huang, R. Discovery of Bisubstrate Inhibitors for Protein NTerminal Methyltransferase 1. J. Med. Chem. 2019, 62, 3773-3779.

(22) Ho, Y. H.; Chen, L.; Huang, R. Development of a Continuous Fluorescence-Based Assay for nTerminal Acetyltransferase D. Int. J. Mol. Sci. 2021, 22, 1-12.

(23) Copeland, R. A. Tight Binding Inhibitors. In Evaluation of Enzyme Inhibitors in Drug Discovery: A Guide for Medicinal Chemists and Pharmacologists, 2nd Ed., John Wiley \& Sons: New Jersey, 2013, 
bioRxiv preprint doi: https://doi.org/10.1101/2021.01.24.427995; this version posted June 3, 2021. The copyright holder for this preprint (which was not certified by peer review) is the author/funder, who has granted bioRxiv a license to display the preprint in perpetuity. It is made available under aCC-BY-NC-ND 4.0 International license.

245-285.

(24) Morrison, J. F. The Slow-Binding and Slow, Tight-Binding Inhibition of Enzyme-Catalysed Reactions. Trends Biochem. Sci. 1982, 7, 102-105.

(25) Khalil, E. M.; Cole, P. A. A potent inhibitor of the melatonin rhythm enzyme. JACS. 1998, 120, 61956196.

(26) Gaudet, R. G.; Guo, C. X.; Molinaro, R.; Kottwitz, H.; Rohde, J. R.; Dangeard, A. S.; Arrieumerlou, c.; Girardin, S. E.; Gray-Owen, S. D. Innate recognition of intracellular bacterial growth is driven by the TIFA-dependent cytosolic surveillance pathway. Cell reports. 2017, 19, 1418-1430.

(27) Chen D, Dong G, Deng Y, Noinaj N, Huang R. Structure-based discovery of cell-potent peptidomimetic inhibitors for protein N-terminal methyltransferase 1. ACS Med. Chem. Lett. 2021, $12,485-495$.

(28) Jafari, R.; Almqvist, H.; Axelsson, H.; Ignatushchenko, M.; Lundback, T.; Nordlund, P.; Martinez Molina, D. The cellular thermal shift assay for evaluating drug target interactions in cells. Nat. Protoc. 2014, 9, 2100-2122

(29) Schneider, C. A.; Rasband, W. S.; Eliceiri, K. W. NIH Image to ImageJ: 25 years of image analysis. Nat. methods. 2012, 9, 671-675.

(30) Collins, J. M.; Porter, K. A.; Singh, S. K.; Vanier, G. S. High-Efficiency Solid Phase Peptide Synthesis (He -Spps). Org. Lett. 2014, 16, 940-943.

(31) Gottlieb, L.; Marmorstein, R. Structure of Human NatA and Its Regulation by the Huntingtin Interacting Protein HYPK. Structure 2018, 26, 925-935.e8.

(32) Deng, S.; Magin, R. S.; Wei, X.; Pan, B.; Petersson, E. J.; Marmorstein, R. Structure and Mechanism of Acetylation by the N-Terminal Dual Enzyme NatA/Naa50 Complex. Structure 2019, 27, 10571070. e4.

(33) Deng, S.; McTiernan, N.; Wei, X.; Arnesen, T.; Marmorstein, R. Molecular Basis for N-Terminal 
bioRxiv preprint doi: https://doi.org/10.1101/2021.01.24.427995; this version posted June 3, 2021. The copyright holder for this preprint (which was not certified by peer review) is the author/funder, who has granted bioRxiv a license to display the preprint in perpetuity. It is made available under aCC-BY-NC-ND 4.0 International license.

Acetylation by Human NatE and Its Modulation by HYPK. Nat. Commun. 2020, 11, 1-14.

(34) McCullough, C. E.; Song, S.; Shin, M. H.; Johnson, F. B.; Marmorstein, R. Structural and Functional Role of Acetyltransferase HMOF K274 Autoacetylation. J. Biol. Chem. 2016, 291, 18190-18198.

(35) Otwinowski, Z.; Minor, W. Processing of X-Ray Diffraction Data Collected in Oscillation Mode. Methods Enzymol. 1997, 276, 307-326.

(36) Adams, P. D.; Afonine, P. V.; Bunkóczi, G.; Chen, V. B.; Davis, I. W.; Echols, N.; Headd, J. J.; Hung, L. W.; Kapral, G. J.; Grosse-Kunstleve, R. W.; McCoy, A. J.; Moriarty, N. W.; Oeffner, R.; Read, R. J.; Richardson, D. C.; Richardson, J. S.; Terwilliger, T. C.; Zwart, P. H. PHENIX: A Comprehensive Python-Based System for Macromolecular Structure Solution. Acta Crystallogr. Sect. D Biol. Crystallogr. 2010, 66, 213-221.

(37) Emsley, P.; Cowtan, K. Coot: Model-Building Tools for Molecular Graphics. Acta Crystallogr. Sect. D Biol. Crystallogr. 2004, 60, 2126-2132. 
bioRxiv preprint doi: https://doi.org/10.1101/2021.01.24.427995; this version posted June 3, 2021. The copyright holder for this preprint (which was not certified by peer review) is the author/funder, who has granted bioRxiv a license to display the preprint in perpetuity. It is made available under aCC-BY-NC-ND 4.0 International license.

Table of Contents graphic

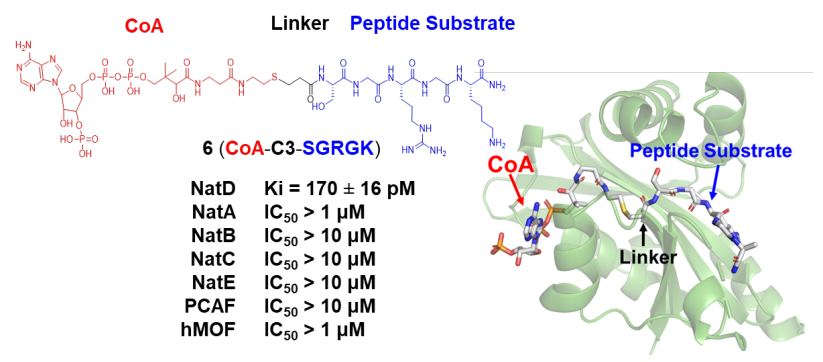




\section{Supporting Information}

\section{Novel bisubstrate inhibitors for protein $\mathrm{N}$-terminal acetyltransferase D}

Youchao Deng ${ }^{\dagger}$, Sunbin Deng ${ }^{\S}$, Yi-Hsun $\mathrm{Ho}^{\dagger}$, Sarah M. Gardner ${ }^{\#}$, Zhi Huang ${ }^{\dagger}$, Ronen Marmorstein ${ }^{\S, \#}$, and Rong Huang ${ }^{*} \dagger$

'Department of Medicinal Chemistry and Molecular Pharmacology, Purdue Institute for Drug Discovery, Purdue University Center for Cancer Research, Purdue University, West Lafayette, Indiana 47907, United States

${ }^{\S}$ Department of Chemistry, University of Pennsylvania, Philadelphia, Pennsylvania 19104, United States

"Department of Biochemistry and Biophysics, Abramson Family Cancer Research Institute, Graduate Group in Biochemistry and Molecular Biophysics, Perelman School of Medicine, University of Pennsylvania, Philadelphia, Pennsylvania 19104, United States

*Corresponding Author: huang-r@purdue.edu 


\section{Table of Contents}

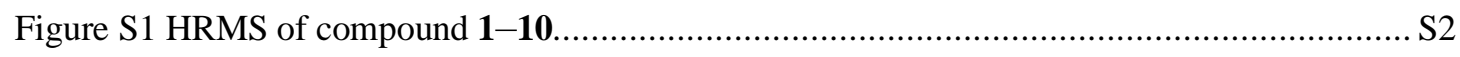

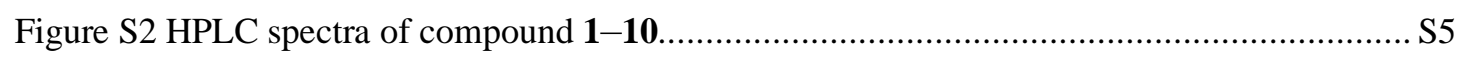

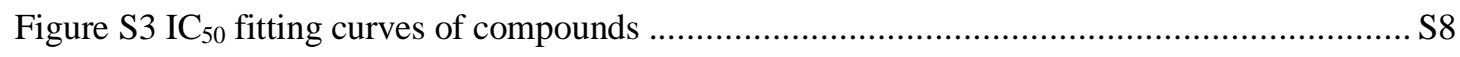

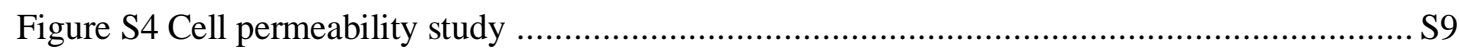

Table S1 Data statistics for NatD crystal structures in complex with inhibitors ..................... S10 
bioRxiv preprint doi: https://doi.org/10.1101/2021.01.24.427995; this version posted June 3,2021 . The copyright holder for this preprint

(which was not certified by peer review) is the author/funder, who has granted bioRxiv a license to display the preprint in perpetuity. It is made available under aCC-BY-NC-ND 4.0 International license.

\section{Figure S1. HRMS of Compound 1-9.}

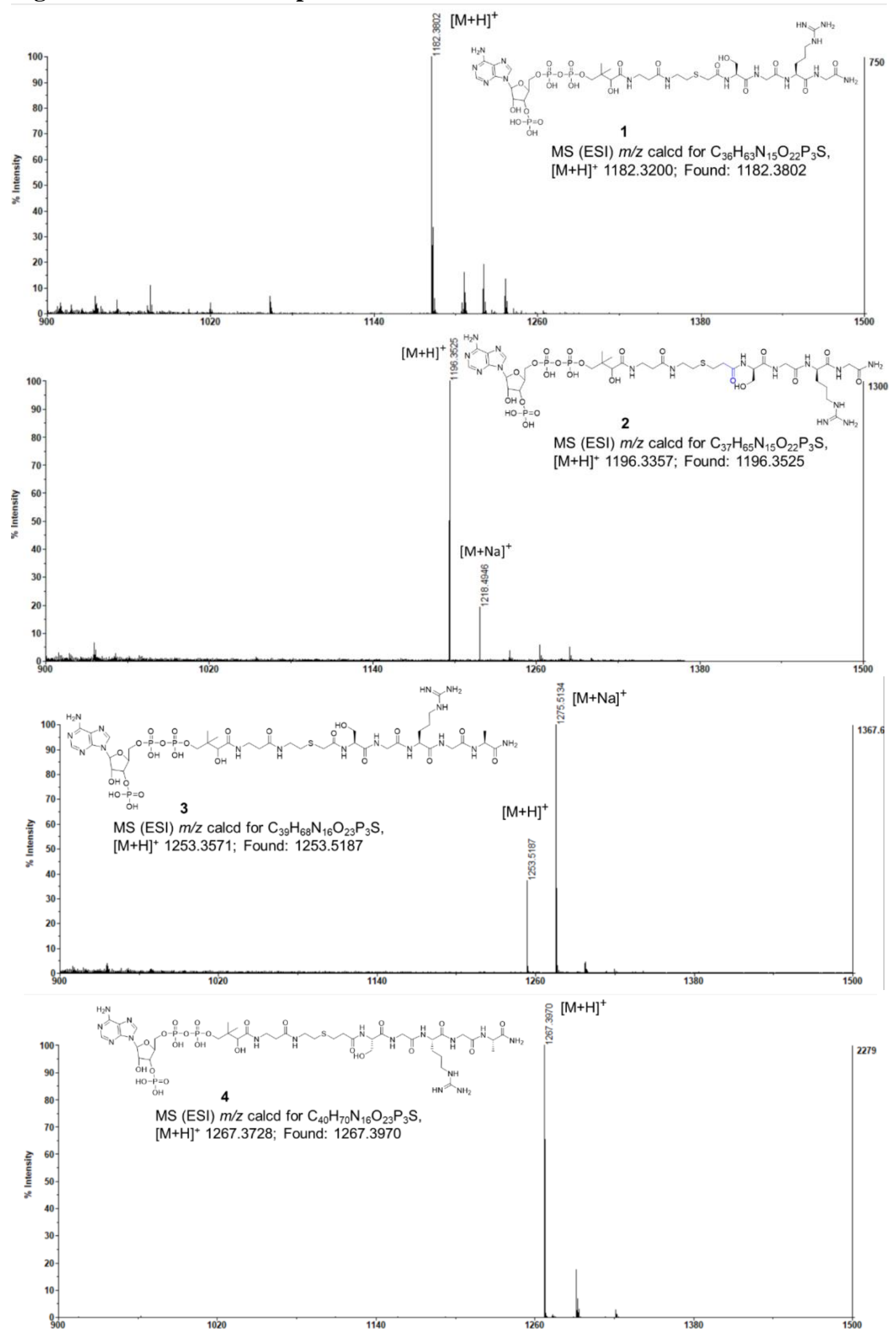


bioRxiv preprint doi: https://doi.org/10.1101/2021.01.24.427995; this version posted June 3, 2021. The copyright holder for this preprint (which was not certified by peer review) is the author/funder, who has granted bioRxiv a license to display the preprint in perpetuity. It is made available under aCC-BY-NC-ND 4.0 International license.
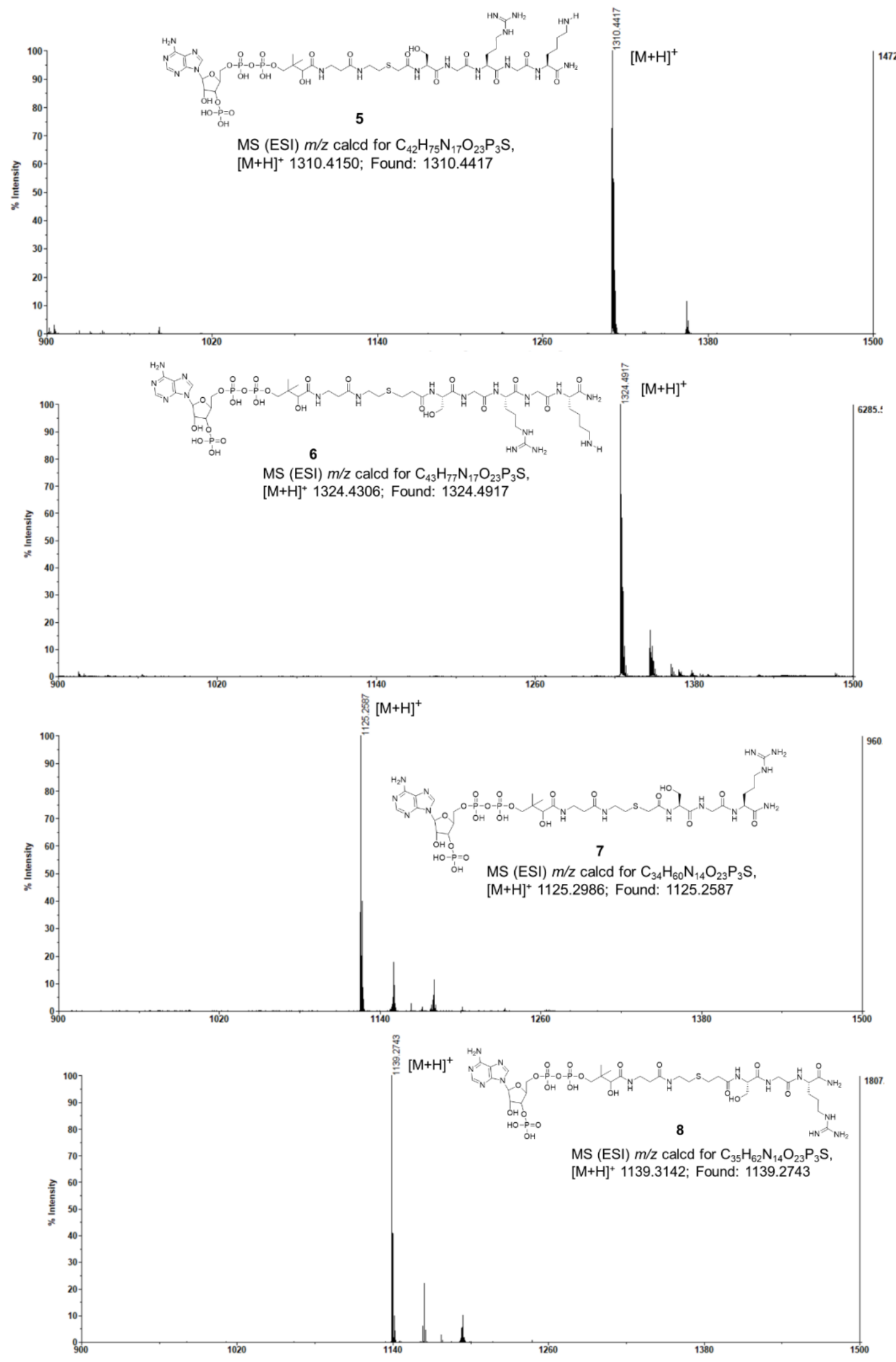
bioRxiv preprint doi: https://doi.org/10.1101/2021.01.24.427995; this version posted June 3, 2021. The copyright holder for this preprint (which was not certified by peer review) is the author/funder, who has granted bioRxiv a license to display the preprint in perpetuity. It is made available under aCC-BY-NC-ND 4.0 International license.

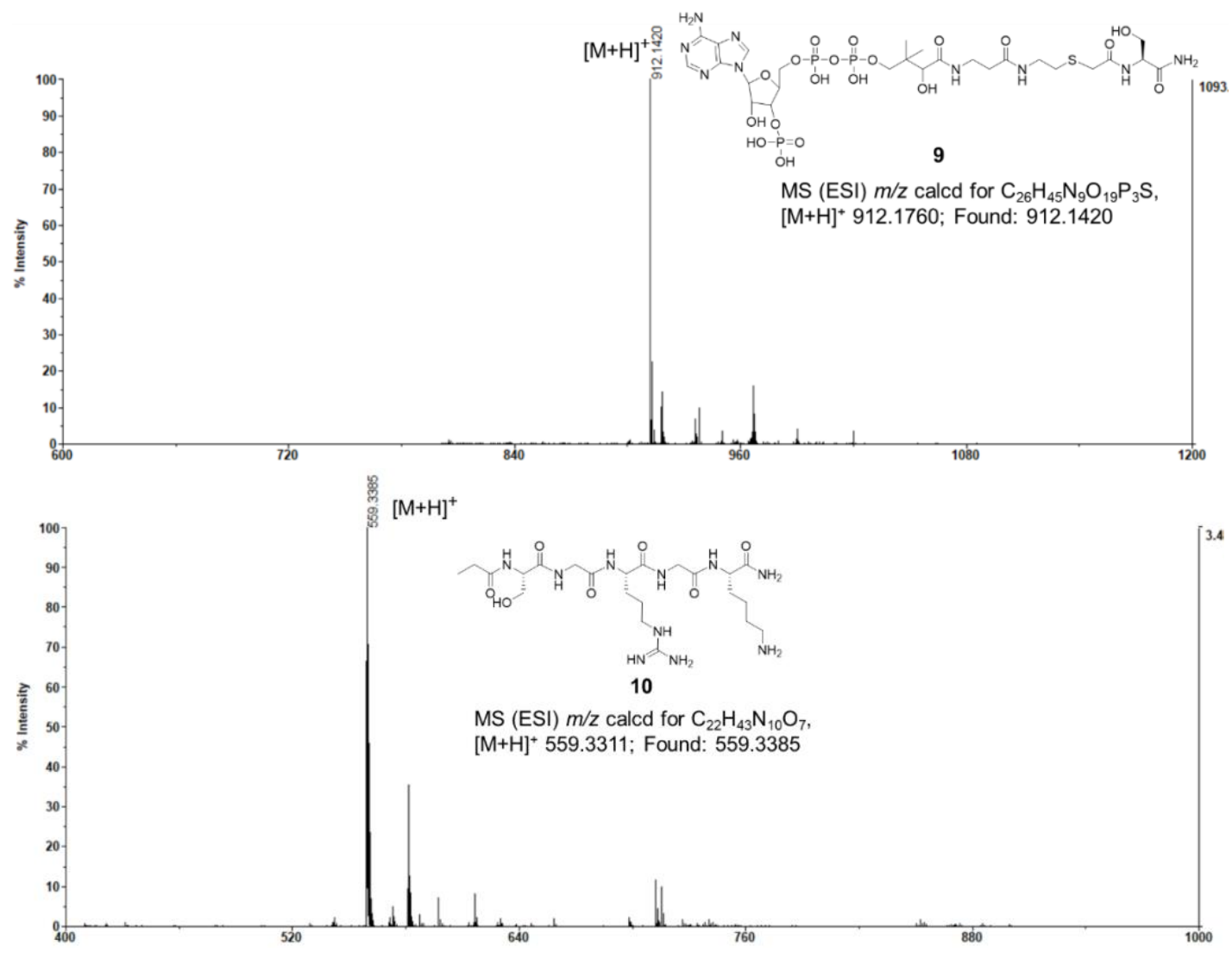


bioRxiv preprint doi: https://doi.org/10.1101/2021.01.24.427995; this version posted June 3,2021 . The copyright holder for this preprint

(which was not certified by peer review) is the author/funder, who has granted bioRxiv a license to display the preprint in perpetuity. It is made available under aCC-BY-NC-ND 4.0 International license.

\section{Figure S2. LC Spectrum of Compound 1-9.}
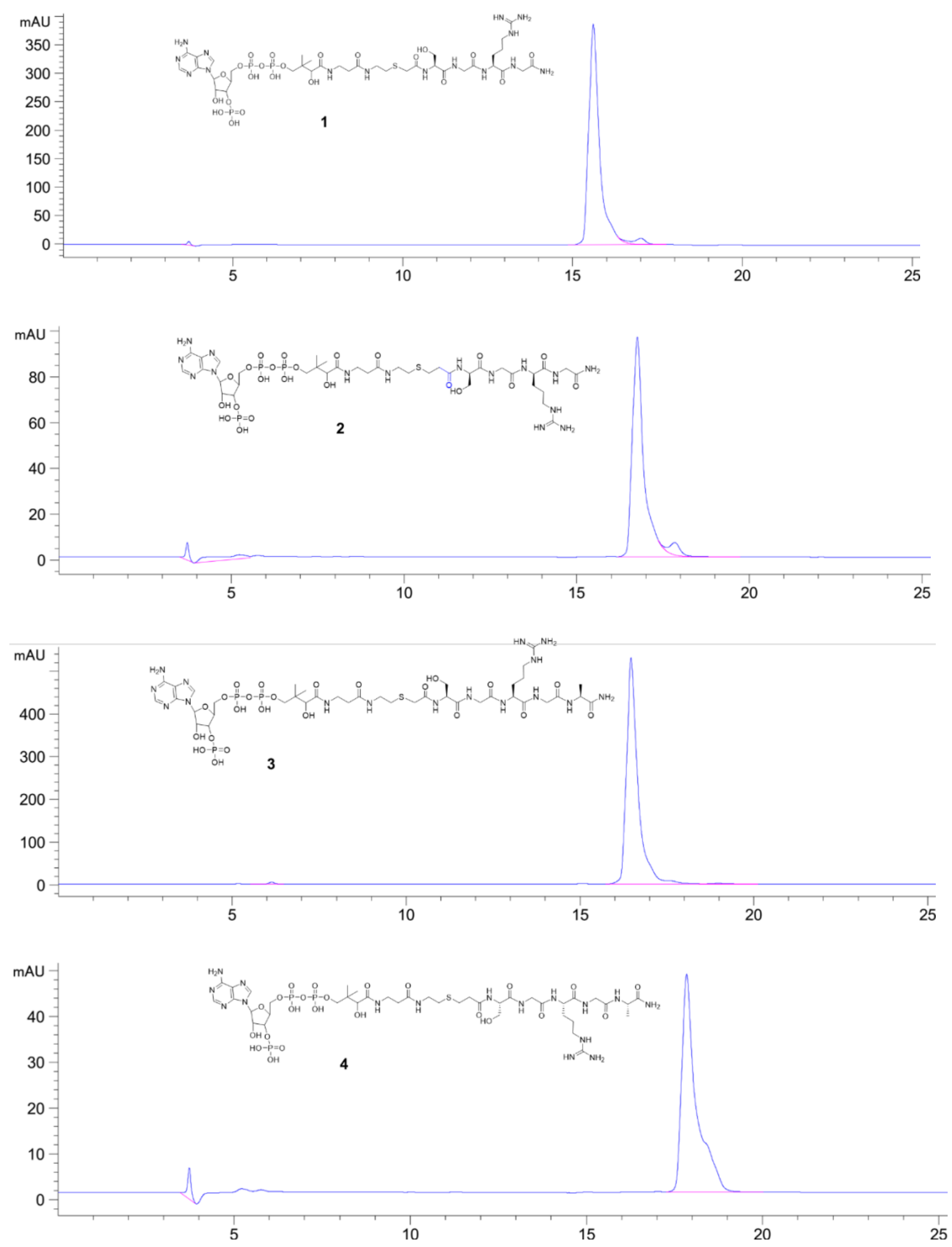
bioRxiv preprint doi: https://doi.org/10.1101/2021.01.24.427995; this version posted June 3, 2021. The copyright holder for this preprint (which was not certified by peer review) is the author/funder, who has granted bioRxiv a license to display the preprint in perpetuity. It is made available under aCC-BY-NC-ND 4.0 International license.
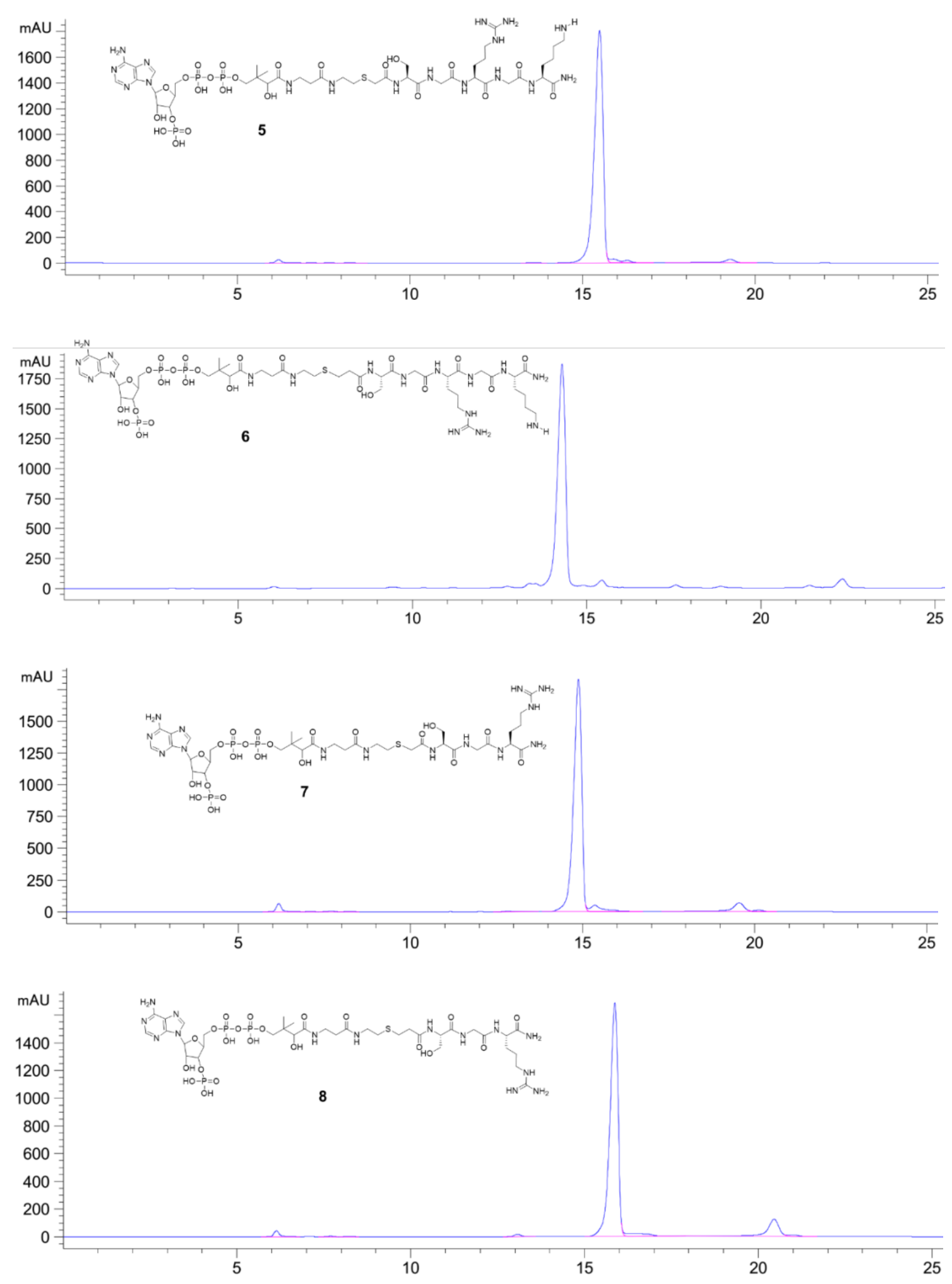
bioRxiv preprint doi: https://doi.org/10.1101/2021.01.24.427995; this version posted June 3, 2021. The copyright holder for this preprint (which was not certified by peer review) is the author/funder, who has granted bioRxiv a license to display the preprint in perpetuity. It is made available under aCC-BY-NC-ND 4.0 International license.
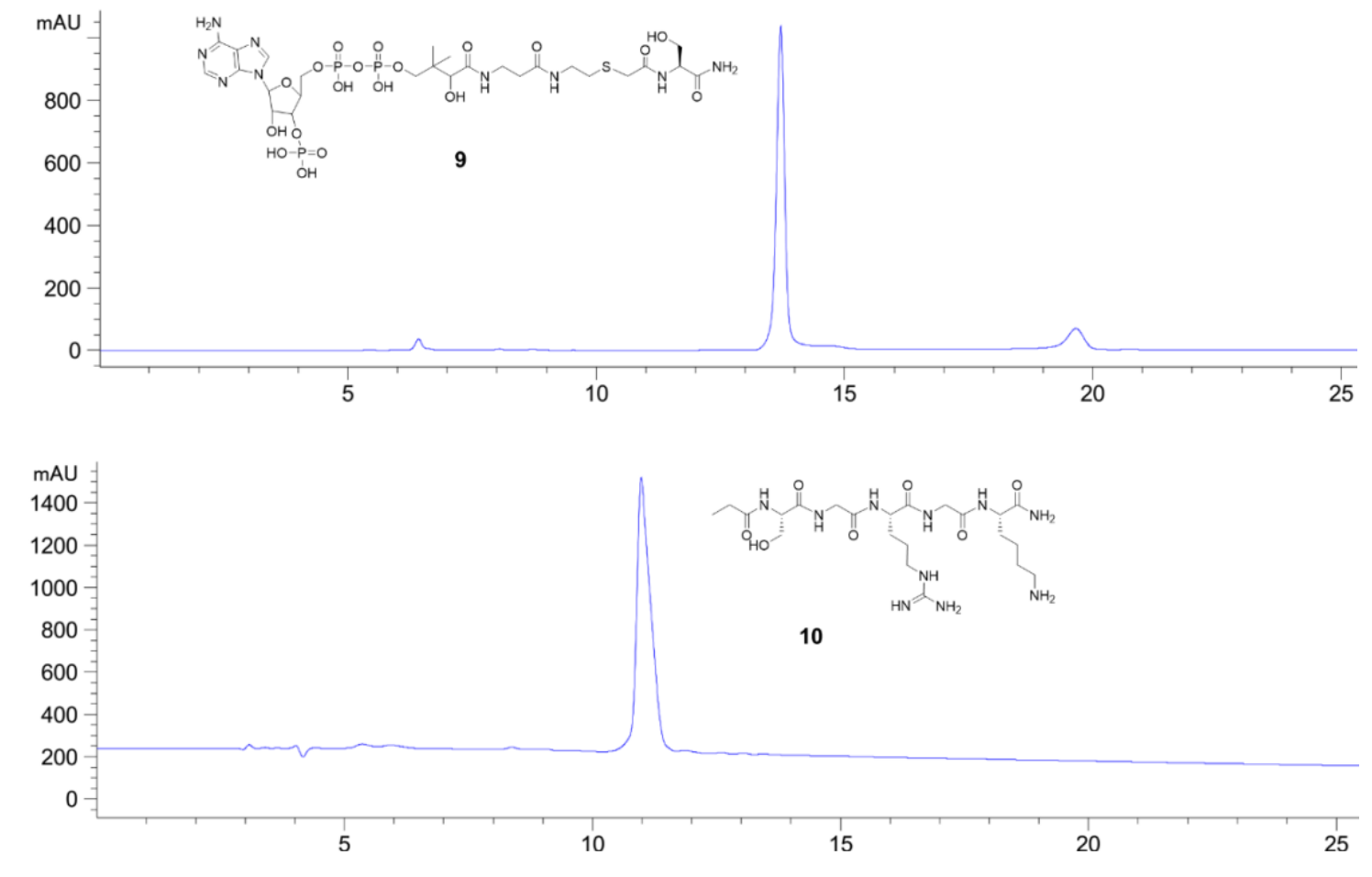

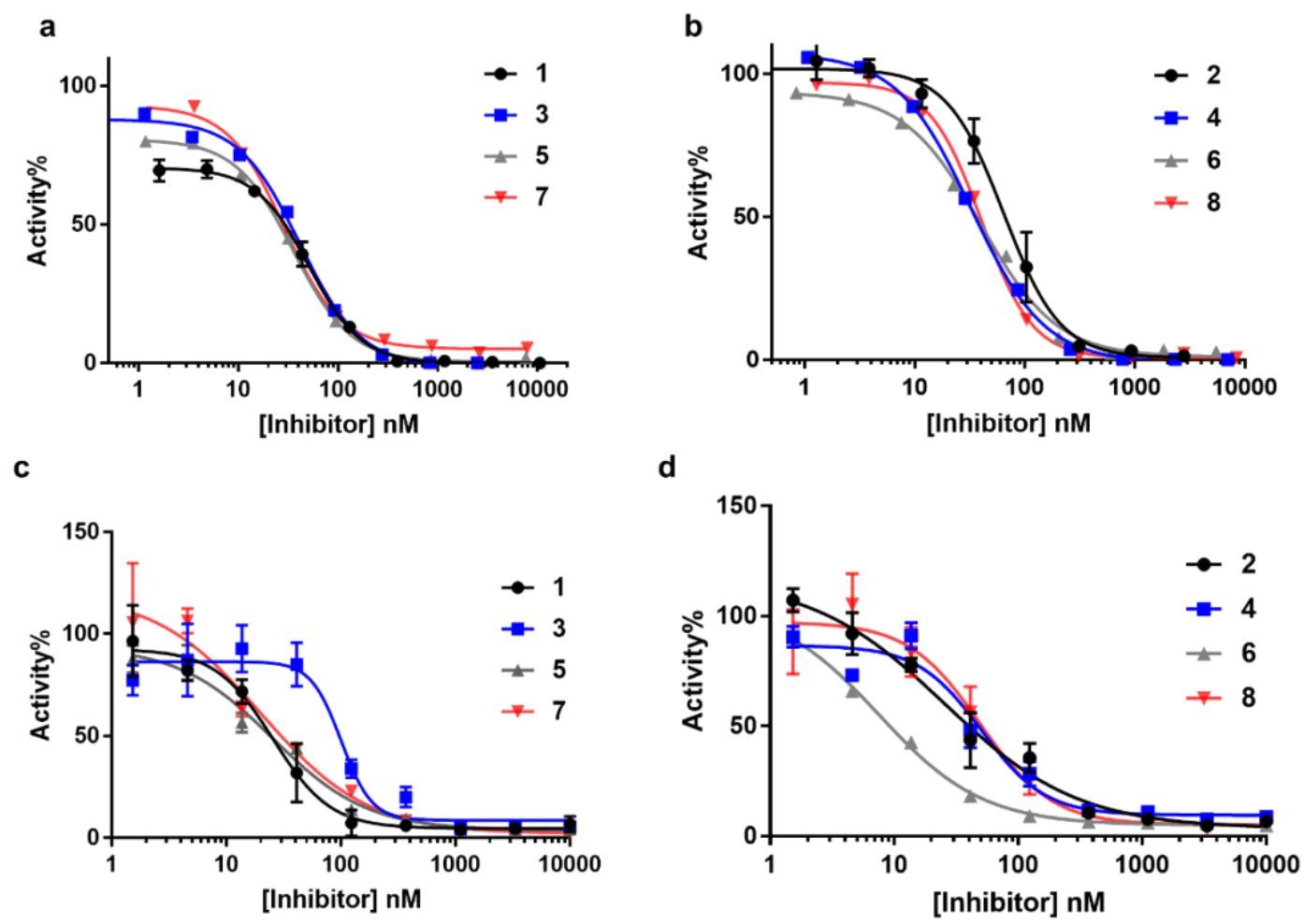

Figure S3. IC 50 fitting curves of compounds in the fluorescence and radio isotopic assay. a) Concentration-response plots of bisubstrate analogues with an acetyl linker under $1 \times \mathrm{Km}$ of $\mathrm{H} 4-8$ peptide and AcCoA condition $(n=2)$ in the fluorescence assay. $b)$ Concentration-response plots of bisubstrate analogues with a propionyl linker under $1 \times K m$ of H4-8 peptide and AcCoA condition $(n=2)$ in the fluorescence assay. c) Concentration-response plots of bisubstrate analogues with an acetyl linker under $4 \mathrm{x} K_{\mathrm{m}}$ of H4-19 peptide and AcCoA condition ( $n=3)$ in the radio isotopic assay. d) Concentration-response plots of bisubstrate analogues with a propionyl linker under $4 \mathrm{x} K_{\mathrm{m}}$ of $\mathrm{H} 4-19$ peptide and $\mathrm{AcCoA}$ condition $(\mathrm{n}=3)$ in the radio isotopic assay. 
a
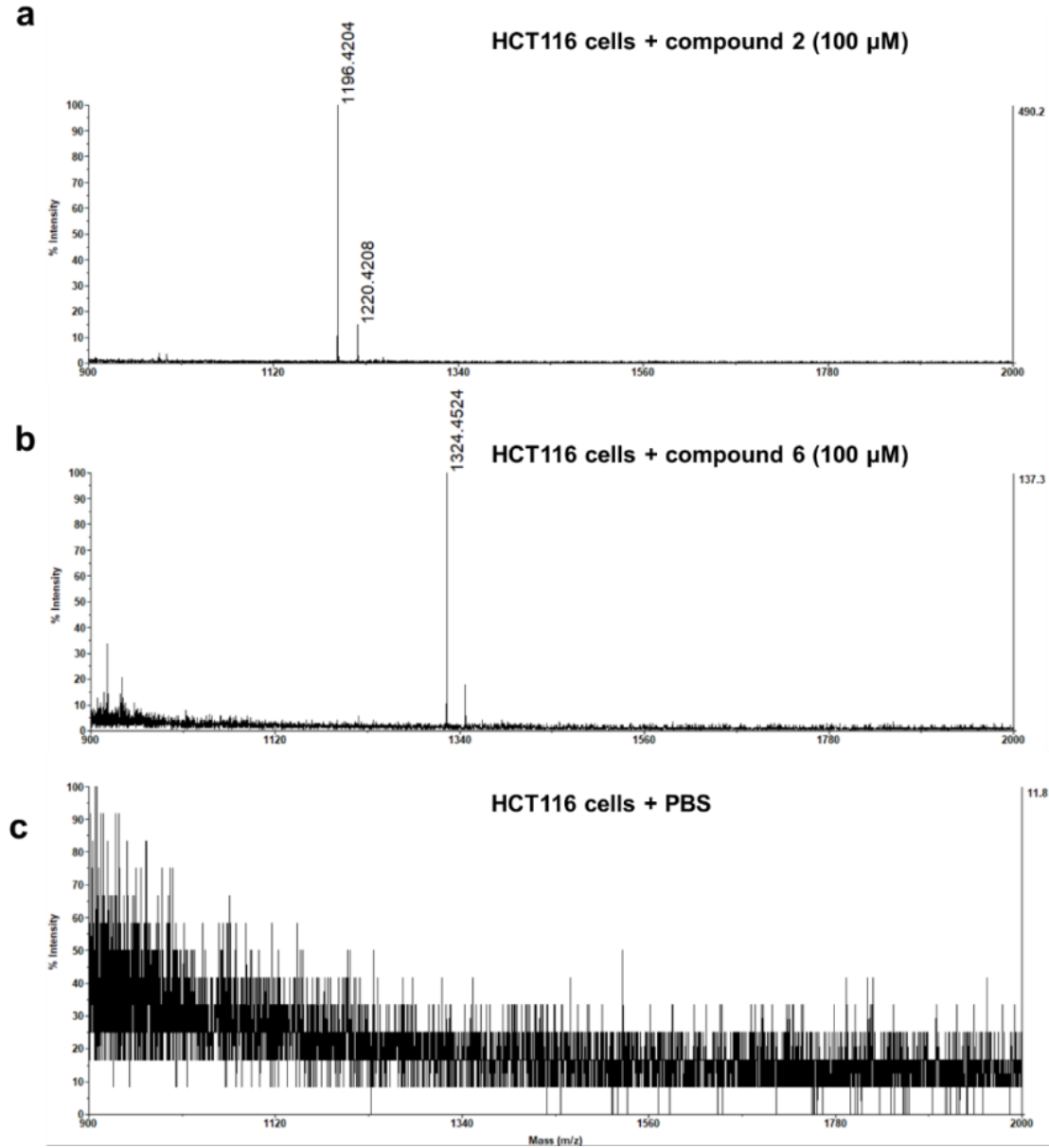

Figure S4. Cell permeability study. a) MALDI-MS for incubation of $100 \mu \mathrm{M}$ compound 2 with HCT116 cells; b) MALDI-MS for incubation of $100 \mu \mathrm{M}$ compound $\mathbf{6}$ with HCT116 cells; c) MALDI-MS for PBS with HCT116 cells. [2+H] $1196.3357,[2+\mathrm{Na}]^{+}$1220.4208; $[6+\mathrm{H}]^{+} 1324.4524$. 


\begin{tabular}{|c|c|c|}
\hline & $\begin{array}{l}\text { NatD bound with } \\
\text { CoA-C2-SGRGK }\end{array}$ & $\begin{array}{l}\text { NatD bound with } \\
\text { CoA-C3-SGRGK }\end{array}$ \\
\hline PDB & 7KD7 & 7KPU \\
\hline \multicolumn{3}{|l|}{ Crystal Parameters } \\
\hline Space group & $\mathrm{P} 2{ }_{1} 2_{1} 2_{1}$ & $\mathrm{P} 2{ }_{1} 2_{1} 2_{1}$ \\
\hline \multirow{3}{*}{$\begin{array}{l}\text { Unit cell dimension } \\
\text { a,b,c }(\AA) \\
\alpha, \beta, \gamma\left(^{\circ}\right)\end{array}$} & $46.433(90)$ & $46.317(90)$ \\
\hline & $74.349(90)$ & $74.164(90)$ \\
\hline & $126.821(90)$ & $127.022(90)$ \\
\hline \multicolumn{3}{|l|}{ Data collection } \\
\hline Wavelength & 0.97918 & 0.97918 \\
\hline Resolution $(\AA)$ & $\begin{array}{l}48.25-1.439 \\
(1.49-1.439)\end{array}$ & $\begin{array}{l}43.51-1.429 \\
(1.48-1.429)\end{array}$ \\
\hline Unique reflections & $79843(7732)$ & $81274(7793)$ \\
\hline$R_{\text {merge }}$ & $0.038(0.661)$ & $0.034(0.244)$ \\
\hline $\mathrm{I} / \sigma$ & $23.1(2.5)$ & $35.9(6.2)$ \\
\hline Completeness & $99.23(97.07)$ & $99.34(96.72)$ \\
\hline Redundancy & $6.4(6.0)$ & $6.5(5.7)$ \\
\hline \multicolumn{3}{|l|}{ Refinement } \\
\hline $\mathrm{R}_{\text {work }} / \mathrm{R}_{\text {free }}$ & $0.1614 / 0.1829$ & $0.1626 / 0.1827$ \\
\hline \multicolumn{3}{|l|}{ R.m.s. deviations } \\
\hline Bonds $(\AA)$ & 0.018 & 0.012 \\
\hline Angels $\left({ }^{\circ}\right)$ & 1.587 & 1.24 \\
\hline Average $B$ factors $\left(\AA^{2}\right)$ & 25.24 & 20.26 \\
\hline Protein & 24.05 & 18.26 \\
\hline Solvent & 36.27 & 31.54 \\
\hline Ligand & 36.13 & 30.25 \\
\hline \multicolumn{3}{|c|}{ Ramachandran statistics (\%) } \\
\hline Favored & 97.79 & 98.72 \\
\hline Allowed & 2.21 & 1.28 \\
\hline Outliers & 0 & 0 \\
\hline
\end{tabular}

Values in parentheses are for the highest-resolution shell. 